\title{
Las relaciones luso-hispánicas en torno a las Misiones Orientales del Uruguay: de los orígenes al Tratado de Madrid, 1750
}

\author{
Fernando Camargo \\ Universidad de Passo Fundo (Brasil) \\ fernando@clio.pro.br
}

\begin{abstract}
Resumen
El presente trabajo constituye un esfuerzo por identificar y contextualizar algunos de los diferentes agentes y factores que influyeron en el proceso de ocupación eficaz del margen izquierdo del río Uruguay, es decir, la Banda Oriental del Uruguay, las Misiones Orientales del Uruguay y el Continente de São Pedro (actualmente República Oriental del Uruguay y estado del Rio Grande do Sul, Brasil), por las metrópolis ibéricas. El análisis se concentra en los orígenes de ese proceso y sus primeras implicaciones diplomáticas en el siglo $\mathrm{XV}$, hasta el Tratado de Madrid, de 1750.

Palabras clave: BRASIL, AMÉRICA PORTUGUESA, URUGUAY, MISIONES ORIENTALES, TRATADO DE MADRID, SIGLO XVIII.
\end{abstract}

\begin{abstract}
The present work is an attempt to identify and contextualize some of the different agents and factors that influenced the effective occupation process of the left margin of the Uruguay river, in other words, the Banda Oriental del Uruguay, the Misiones Orientales del Uruguay and the Continente de São Pedro (now Republica Oriental del Uruguay and state of Rio Grande do Sul - Brazil), by the Iberian metropolises, from the origins of that process and its first diplomatic implications in the $15^{\text {th }}$ century, until the Treaty of Madrid, 1750 .
\end{abstract}

Key words: BRAZIL, PORTUGUESE AMERICA, URUGUAY, WEST MISSIONS, TREATY OF MADRID, $18^{\mathrm{TH}}$ CENTURY. 
Las Misiones Orientales del Uruguay, bajo la óptica que aquí se propone, se consideran como una región de frontera y, como tal, objeto básico de conflictos territoriales entre las metrópolis ibéricas, tal como sucedió en otras zonas que asumieron un papel similar en los márgenes de Suramérica.

Fue bajo una perspectiva geopolítica ${ }^{1}$ que los límites de las posesiones portuguesas y españolas de ultramar habían tenido sus primeras definiciones. No es difícil percibir esto, especialmente porque los tratados mismos, desde el de de Alcáçovas, en 1479, apuntan hacia la idea de unos límites artificialmente concebidos, que obedecen a una lógica territorial, construida en mapas y planos en gabinetes europeos. El Tratado de Alcáçovas, además de definir la cuestión dinástica de Castilla, reservó a Portugal la preeminencia en una región -el golfo de la Guinea-, cuyo conocimiento geográfico era todavía escaso:

Cuando D. Joao II subió al trono, el tratado de Alcaçovas hacía poco se había firmado, dos años antes, en 1479, definiendo la sucesión de Castilla y delimitando las zonas de influencia al sur de la península ibérica: el golfo de Guinea fue reservado a Portugal $^{2}$.

Esta delimitación de zonas de influencia fue el principio de una práctica diplomática que iría ampliándose durante más de tres siglos y medio y que acabaría por exigir casi una docena de nuevos tratados. Este acuerdo fue un marco de referencia, en el sentido de que fue uno de los primeros en establecer "zonas de influencia" entre las potencias, una de las características de las prácticas imperialistas:

La renuncia de $\mathrm{D}$. Alfonso $\mathrm{V}$ a las pretenciones al trono de Castilla tuvo su contrapartida en el reconocimiento "para siempre" por parte de los reyes españoles, de todas las conquistas portuguesas en África, la India y el Atlántico, con excepción de las Canarias, que siguieron siendo de Castilla. Así fue establecido por el Tratado de Alcáçovas, de $1479^{3}$.

La idea de que era posible dividir todo el planeta en grandes regiones de dominio particular y exclusivo de determinados reinos, se afianzó a partir de las bulas papales sobre posesiones y

\footnotetext{
${ }^{1}$ La expresión "geopolítica", como se utiliza a lo largo de este texto, tiene un sentido amplio y sin relación con las valoraciones que le fueron atribuidas cuando nació el término (en 1916, con Rudolf Kjellén) y con su utilización posterior por Haushofer. Se utiliza aquí la definición propuesta por Philippe Moreau: "Siguiendo una definición tan simple como sea posible, la geopolítica se interroga sobre las relaciones entre el espacio (en todos los sentidos de la palabra) y la política". ["Segundo uma definição tão simples quanto possível, a geopolítica interroga-se sobre as relações entre o espaço (em todos os sentidos da palavra) e a política"]. Philippe Moreau Defarges, Introdução à geopolítica (Lisboa: Gradiva, 2003), 7.

${ }^{2}$ Marc Ferro, História das colonizações: das conquistas às independências, séculos XIII a XX (São Paulo: Companhia das Letras, 1996), 44.

3 "A desistência de $\mathrm{D}$. Afonso $\mathrm{V}$ às pretensões ao trono de Castela teve a sua contrapartida no reconhecimento "para sempre" por parte dos reis espanhóis, de todas as conquistas portuguesas em África, até a Índia, e no Atlântico, com excepção das Canárias, que ficariam para Castela. Assim se estabeleceu pelo Tratado de Alcáçovas, de 1479”. Pedro Martínez Soares, História diplomática de Portugal, 2a. ed. (Lisboa: Verbo, 1992), 86.
} 
límites, entre las cuales se destaca la bula Inter Catera, del Papa Alejandro VI, del 4 de mayo de 1493. Con certeza, a pesar de que este fue un primer intento de creación de un sistema global de poderes, esta Bula fue, al mismo tiempo y de manera paradójica, una de las ultimas manifestaciones de la lógica feudal, según la cual todas las tierras del mundo pertenecían a la representación física de Dios: la Iglesia de Roma. Este viejo universalismo, oriundo de los primeros tiempos del feudalismo, a pesar de no estar explícito, queda claro en la misma postura papal al disponer de la organización territorial del planeta ${ }^{4}$.

En el documento de Alcaçovas, se nota que falta la intención de establecer límites fijos definitivos y en lugar de esto se establecen contornos flexibles en torno a esferas de acción:

[...] hizo [el Papa] su divisoria conocedor como era de la naturaleza humana, quiso establecer tan sólo una divisoria ideal, imaginaria, inexistente, ficticia, como se diría ahora, según la intepretación que se le venga dando, o, en otros términos: una separación real, física, material, interponiendo entre ambas coronas y sus ambiciones similares, una zona real de separación y alejamiento - un verdadero huso geográfico, sustrayendo de esta manera la zona por este comprendida, del dominio de los dos monarcas 5 .

Esta injerencia del catolicismo romano en los asuntos internos y externos de los estados ibéricos dejó profundas huellas en el tejido social y simbólico de aquellas poblaciones, cuyos ecos aun subsisten. El traspaso de esa misma ingerencia en las colonias ibéricas de América tuvo las mismas consecuencias, quizá dejando marcas aun más fuertes y persistentes.

La importancia de percibir y señalar el papel desarrollado por la Iglesia en todo este proceso es consecuencia del hecho de que el proceso de constitución del sistema social, político y económico denominado "guaraní-misionero", antes de ser una empresa española, fue una empresa católica. La ausencia de los gestores de esta empresa, es decir, los padres de la Compañía de Jesús, a partir de la segunda mitad del siglo XVIII, fue el origen de la decadencia de aquel sistema, abriendo la posibilidad de absorción del espacio que ocupaban -en términos geopolíticos y económicos- otros grupos. De la posibilidad vino la codicia. De la codicia vino el conflicto.

El siguiente paso en el desarrollo de instrumentos para solucionar cuestiones entre las Coronas ibéricas fue el tratado de 1494. Esta vez se asumió un acuerdo de carácter más temporal, con la presencia y la bendición de la Iglesia de Roma. Fue firmado después de los debates llevados a

\footnotetext{
${ }_{5}^{4}$ Ibídem, 93.

5 “[...] fixou [o Papa] sua divisoria conhecedor como era da natureza humana, quiz estabelecer tão sómente uma divisoria ideal, imaginaria, inexistente, ficticia, como se diria agóra, segundo a interpretação que se vem dando ou, em outros termos: uma separação real, fisica, material, interpondo entre ambas as corôas e suas ambições iguais, uma zona real de separação e afastamento -um verdadeiro fuso geografico, subtraindo, assim, a zona por êste compreendida do dominio dos dois monarcas". Emílio F. de Souza Docca, Limites entre o Brasil e o Uruguai (Rio de Janeiro: Oficina Gráfica do Establecimiento Central de Intendencia, 1939), 7 y 8.
} 
cabo en Tordesillas, centro-norte de la España actual, entre los representantes de don Joao II, de Portugal, de un lado, y los representantes de los reyes católicos, Isabel y Fernando, del otro ${ }^{6}$. Las diferencias con relación a Alcaçovas y a las bulas son muchas, tanto por su carácter y naturaleza, como por su extensión y significado. Pero algunos elementos profundos son recurrentes en todos los casos. Llama la atención, por ejemplo, que, una vez más, son acuerdos arbitrariamente construidos y no basados en una formación histórica. Esto quiere decir que en lugar de dirimir antagonismos, lo cual constituye el objetivo principal de la aplicación de acuerdos diplomáticos, estos tratados, al mismo tiempo, anunciaban e incitaban el conflicto.

La utilización de expresiones tales como tierras halladas y por hallar ${ }^{7}$, es una manifestación sincera y ruidosa de la absoluta ignorancia o poco conocimiento que tenían sobre los objetos esenciales de los acuerdos mismos. La magnitud de lo que fue entregado a las monarquías involucradas en el proceso era algo difícil de imaginar o de concebir, aun por los individuos más sabios de la época: "El Tratado de Tordesillas [...], también dejaba un margen para las dudas, sobre todo en cuanto a los instrumentos adecuados para fijar una línea ajustada" ${ }^{\text {. }}$. Este tratado nació, por ejemplo, con vicios diplomáticos, pues a partir de la letra menuda del texto podía ser deducida la suposición de que las otras monarquías cristianas de Europa reconocidas por las coronas ibéricas, estarían incluidas en la división?

De imposible ejecución literal, estos acuerdos y tratados, en verdad, pretendían mucho más la creación de esferas de influencia y su futura defensa jurídico-política. No era de esperarse que fueran respetados por las poblaciones locales involucradas o por las demás naciones cristianas europeas. Fueron elaborados, eso sí, para que fueran respetados por las dos grandes participantes en la carrera naval de los siglos XV y XVI: Portugal y España. Este cuadro se alteraría drásticamente con el surgimiento de nuevos participantes, a partir de la segunda mitad del siglo $\mathrm{XVI}^{10}$, pero no se alteraría el hecho jurídico para las dos naciones contratantes, al menos hasta 1713, con el Tratado de Utrecht ${ }^{11}$.

La idea de que Tordesillas fue un tratado más sistémico ${ }^{12}$ que simplemente un acuerdo sobre límites, ha sido retomada, quizá con exageración, como si fuera un preludio de lo que hoy la gente llama "globalización". Pero aparte de esto, resulta correcto suponer que se movían

\footnotetext{
${ }^{6}$ Martínez, História, 94. Según el autor, el Tratado de Tordesillas fue necesario porque la bula papal "não era de molde a contentar os portugueses". Para un examen más completo del texto del tratado, ver la traducción en José Carlos de Macedo Soares, Fronteiras do Brasil no Regime Colonial, Coleção Documentos Brasileiros 19 (Rio de Janeiro: Livraria José Olympio Editora, 1939), 69-84.

${ }^{7}$ Soares, Fronteiras, 73.

8 "O Tratado de Tordesilhas [...], também deixava margem a dúvidas, sobretudo quanto aos instrumentos adequados para fixar a linha ajustada". Martínez, História, 94; Souza, Limites, 7; señala la falta de ejecución del tratado.

${ }^{9}$ El rey francés, Enrique, hubiera hecho broma del tema, cuestionando si Francia pertenecería a Portugal por haber quedado al este de la línea meridiana.

${ }^{10}$ Principalmente Inglaterra, Francia y Holanda.

${ }^{11}$ En verdad, la letra del Tratado de Madrid de 1750 anulaba los efectos del de Tordesillas, pero el Tratado de Utrecht no cuestionaba la posesión portuguesa en el área explorada por las incursiones de las Entradas y de las Bandeiras luso-brasileñas.

${ }^{12}$ En el sentido de representar una acomodación de fuerzas; un establecimiento de sistemas de poder.
} 
engranajes de gran tamaño y que se creaba una de las plataformas jurídicas de lo que vendría a constituir el sistema colonial, con una duración de más de tres siglos:

Todavía más increible es el hecho de que el Tratado de Tordesillas haya sido respetado. Fue la base de entendimiento global entre los poderes ibéricos que les permitió ejercer durante decenas de años una hegemonía naval bipartita, en torno a la cual se articuló toda la peculiar relación de fuerzas del primer sistema mundial. Sin él, difícilmente se habría formado esa red de relaciones multifacéticas que abarcó todos los continentes y alteró la cotidianidad de la mayor parte de la humanidad. Por ese motivo podemos considerar que el primer sistema mundial comenzó en 1494, justamente una fecha intermedia entre los dos viajes pioneros que abren las principales rutas oceánicas de altura ${ }^{13}$.

Tordesillas nació destinado a ser desobedecido en la práctica por ambas potencias contratantes. España por el descubrimiento y posterior conquista del archipiélago de las Filipinas, y Portugal, en el proceso de expansión vicentina ${ }^{14}$, desde la Unión Ibérica, en $1580^{15}$. La unión de las Coronas ibéricas en la persona de Felipe II, incluso, implicó la inutilidad teórica del Tratado de Tordesillas.

La flexibilización de los límites ibéricos suramericanos, que comenzó a partir de 1580, permitió, entre otros factores, que el proceso expansionista vicentino, conocido como bandeirantismo o ciclo de las entradas y bandeiras, pudiera ocurrir. Como súbditos del mismo soberano, los vicentinos estaban más tranquilos al traspasar los límites de Tordesillas y buscar nuevas alternativas económicas ${ }^{16}$, más allá de la línea de 370 leguas $^{17}$ :

\footnotetext{
13 “Ainda mais incrível é o fato do Tratado de Tordesilhas ter sido respeitado. Foi a base do entendimento global entre os poderes ibéricos que lhes permitiu exercer durante dezenas de anos uma hegemonia naval bipartida formou o eixo à volta do qual se articulou toda a peculiar relação de forças do $1^{\circ}$ sistema mundial. Sem ele, dificilmente se teria formado essa rede de ligações multifacetadas que abarcou todos os continentes e alterou o quotidiano da maior parte da humanidade. Por esse motivo, podemos considerar que o $1^{\circ}$ sistema mundial começa em 1494, justamente uma data intermédia entre as duas viagens pioneiras que abrem as principais rotas oceânicas da altura". António José Telo, Do Tratado de Tordesilhas à Guerra Fria: reflexões sobre o sistema mundial (Blumenau: Editora da FURB, 1996), 13-14.

${ }^{14}$ El término vicentino(a) se refiere a la Capitania de São Vicente. Es decir, los "paulistas" originales.

${ }^{15}$ La batalla de Alcazar-Quivir, en 1578, fue una frustrada tentativa portuguesa de recuperación y expansión en el Marruecos actual y resultó en la posible muerte del joven rey don Sebastião, que fue reemplazado, en el trono, por el cardenal don Henrique. Como no había herederos directos, debido a la dificultad de Henrique para designar sucesor, con su muerte, en 1580, se abrió la sucesión que llevó al trono al soberano español Felipe II (Felipe I, en Portugal), inaugurando el periodo llamado "Unión Ibérica", que fue una unión personal de las dos Coronas, las cuales permanecieron independientes entre si. Esta situación duró hasta la llamada Restauración de Portugal, en 1640.

${ }^{16}$ Buscaban, con más ahínco, metales, piedras preciosas y esclavos indígenas, ya que no podían competir con los artículos coloniales de mayor demanda, como el azúcar.

17 "[...] os bandeirantes contavam com a tolerância, quando não com a conivência das autoridades de Assunção e Buenos Aires". Moniz Bandeira, O expansionismo brasileiro: o papel do Brasil na Bacia do Prata-Da colonização ao império (Rio de Janeiro: Philobiblion, 1985), 26.
} 
Los luso-brasileros, por el contrario, no encontraron nada más que palo brasil y nunca se conformaron con el hecho de no haber descubierto en sus dominios minas de oro y plata, tan abundantes en las posesiones españolas. La búsqueda de Eldorado, que nombres como el Perú y Potosí simbolizaban, los llevó, de esta manera, a iniciar el avance por el hinterland de América del Sur, rompiendo la línea de demarcación que estableció el Tratado de Tordesillas ${ }^{18}$.

Durante el mismo periodo de 1580 a 1640 ocurrió la primera fase de la formación de las reducciones jesuítico-guaraníes, que iban a desarrollar todo un sistema social y económico, en una vasta área comprendida entre el sur del actual Paraguay, el nordeste de la actual Argentina y la región central objeto de este estudio, ya descrita. Estos movimientos, comenzando con un carácter más privado y espontáneo, definieron algunas directrices políticas que iban a asumir las coronas ibéricas a partir del siglo XVIII.

La construcción del espacio "guaraní-misionero" en Suramérica pudo desarrollarse, inicialmente, por el beneplácito de las autoridades coloniales, especialmente por los primeros adelantados del Paraguay. Hernando Arias de Saavedra ${ }^{19}$ fue uno de los primeros en resaltar la necesidad de civilizar y cristianizar las almas que vivían por los campos y en los montes de su jurisdicción. La tarea fue delegada a los hermanos de la Compañía de Jesús en la segunda mitad del siglo XVI.

En este punto, ya se configuraban dos mundos distintos en el universo de la colonización española en la región del río de la Plata. Uno rural, de economía primaria y poco normatizado, y otro urbano, de economía terciaria ${ }^{20}$ y altamente normatizado. De esta dicotomía iba a surgir una tensión insoluble entre ambos mundos, superada únicamente por los procesos de revolución agrícola e integración del ambiente rural, durante el siglo XX, aunque no del todo ${ }^{21}$. El mundo jesuítico no encajaba en este esquema, pues fue simultáneamente, urbano y rural, de economía basada en la agroindustria (economía primario-secundaria) y con normativización diferenciada. De este modo, era muy diferente del restante espacio colonial español en Suramérica. Este punto de vista distingue tres elementos, donde otros perciben solamente dos:

\footnotetext{
18 "Os luso-brasileiros, pelo contrário, nada encontraram além de pau-brasil e nunca se conformaram com o fato de não descobrirem, em seus domínios, minas de ouro e prata, tão abundantes nas possessões espanholas. A busca do Eldorado, que então nomes como o Peru e Potosí simbolizavam, levou-os, assim, a iniciarem o avanço pelo hinterland da América do Sul, rompendo a linha de demarcação que o Tratado de Tordesilhas estabelecera". Bandeira, $O$ expansionismo, 23.

${ }^{19}$ También conocido como Hernandarias.

${ }^{20}$ Las grandes ciudades orbitaban, económicamente, en torno al comercio de larga escala y de las actividades administrativas y burocráticas.

${ }^{21}$ Este proceso fue asumiendo, paulatinamente, nuevas proporciones con la creciente concentración política y económica en torno a ciudades portuarias como Montevideo y Buenos Aires. Las "dos Argentinas" o la dicotomía entre "civilización y barbarie" pueden ser observadas en: Emanuel Soares da Veiga García, As duas Argentinas, Série Princípios 194 (São Paulo: Ática, 1990), 7-54; Francisco Viana, Argentina, civilização e barbárie, Série História Viva (São Paulo: Atual, 1990), 8-33.
} 
[...] se configura también, ya desde el siglo XVI, una sociedad dual, que se basa en la estricta delimitación de dos grandes comunidades étnicas y culturales denominadas oficialmente la república de los españoles la república de los indios, con legislación propia y diferenciada. [...] La inicial estructura dual se mantiene y se acentúa en los siglos siguientes, y se hará más o menos equivalente a sociedad urbana o hispanizada y sociedad rural o indianizada ${ }^{22}$.

Las misiones religiosas, en general, y las jesuíticas, en particular, fueron células urbanas en la frontera de la "ruralidad". Aglomeraciones humanas perdidas en medio de la amplitud continental suramericana, aisladas de los principales polos urbanos de la América española colonial, por opción y por la geografía:

A medida que la población indígena disminuía debido a las enfermedades y los demás efectos de la conquista, los frailes fundaron nuevos asentamientos -las reducciones o congregaciones- en los cuales fueron forzadas a establecerse poblaciones dispersas, con el fin de facilitar el proceso de conversión y la aculturación en términos europeos ${ }^{23}$.

La opción por el aislamiento representaba la opinión generalizada entre los religiosos en torno a la noción de una pureza infantil y original de las poblaciones indígenas en general. Este tipo de postura, en la cual está implícito el discurso de la corrupción del salvaje por el blanco, es consecuencia del desequilibrio entre los dos grandes vórtices de atracción colonial desde el siglo XVI: el de la riqueza y retorno, y el de la catequesis y permanencia. Este discurso tiene la marca imborrable de las crónicas y discursos del padre dominicano Bartolomé de Las Casas, pero su origen se remonta a los primeros evangelizadores del Nuevo Mundo:

Todos estáis en pecado mortal y en él vivís y morís, por la crueldad y tiranía que usáis con estas inocentes gentes. Decid, ¿con qué derecho y con qué justicia tenéis en tan cruel y horrible servidumbre a aquestos indios? ¿Con qué autoridad habéis hecho tan detestables guerras a estas gentes, que estaban en sus tierras mansas y pacíficas, donde tan infinitas dellas, con muerte y estragos nunca oídos, habéis consumido ${ }^{24}$

\footnotetext{
${ }^{22}$ María L. Laviana, La América española, 1492-1898: de las Indias a nuestra América, Colección Historia de España 14 (Madrid: Ediciones Temas de Hoy, 1996), 68. La opinión anotada se refiere más al tema de los estamentos sociales legalmente constituidos y su configuración geográfica a partir de una óptica específica y dualista y, dentro de este esquema, se la debe considerar correcta. Lo que se propone, sin embargo, es un abordaje social más amplio, que permita identificar otros matices intermedios y, a partir de esto, una mejor visualización de la inserción de las sociedades jesuítico-guaraníes en el sistema colonial.

${ }_{23}$ "As the Indian population declined due to disease and the other effects of conquest, friars founded new settlements -the reducciones, or congregaciones - into which dispersed populations were forcibly moved so as to facilitate the process of conversion and acculturation in Europeans ways". Edwin Early et al., History Atlas of South America (Nueva York: MacMillan, 1998), 54.

${ }^{24}$ Laviana, La América, 36. Esta es una trascripción del sermón Ego vox clamantis in deserto pronunciado por el fraile Antón de Montesinos, en Santo Domingo (1511), que fue uno de los gritos iniciales de la batalla política trabada entre colonos y religiosos españoles, relativa a los indios, su naturaleza y sus derechos.
} 
El enfrentamiento de estas dos posturas se alimentaba del crecimiento de la empresa colonial, con un significativo alargamiento de su proyección geográfica y, por lo tanto, alcanzando a un número creciente de poblaciones indígenas. Por otro lado, el impacto de la conquista y colonización del mundo americano provocó en Europa una nueva discusión, esta vez de carácter más filosófico que teológico, sobre la cuestión indígena. Posturas ligadas a lo que posteriormente Rousseau consagraría con la noción del bon sauvage pasarían a circular ampliamente.

La necesidad de apartar a los indígenas de la atracción pecaminosa y de la sed de riquezas de los blancos se convirtió en la tónica constante de los discursos:

[...] solicitábamos que nos dieran mil leguas a lo largo de la costa septentrional, en las que se harían fortalezas de ciento y cien leguas, y otras tierras adentro, en triángulo [...]. Las fortalezas las queríamos más para defendernos de los españoles que de los indios ${ }^{25}$.

Las reducciones indígenas se caracterizaban por esta tentativa constante de aislamiento, en la cual los padres buscaban el mínimo posible de contacto con el restante laico del imperio colonial español. De ahí la afirmación de que constituyeron espacios simultáneamente rurales y urbanos. En la práctica, los contactos eran más frecuentes de lo que podrían desear los religiosos, pero, aun así, se quedaban cortos al permitir una integración más activa y profunda con los centros urbanos de mayor importancia, como Asunción, Santa Fe, Buenos Aires y Montevideo.

En cuanto al aspecto económico, las misiones jesuítico-guaraníes, también ejercieron un papel diferenciado dentro de las economías de los ambientes circundantes, con un tipo de producción accesoria, marginal al ciclo productivo principal de la América andina: la minería. El cerro de plata de Potosí fue, como otros centros mineros de la región, la posesión más preciosa del virreinato de Perú. Pero la necesidad creciente de productos de consumo inmediato y de primera necesidad abrió nuevas posibilidades y nuevos frentes de explotación económica. Cueros, pieles, yerba-mate y granos permitieron un desarrollo interno incipiente de áreas marginales vinculadas a la producción minera.

Resulta curioso que estos dos fenómenos, el bandeirantismo vicentista y las misiones jesuíticoguaraníes, hayan tenido un modelo de desarrollo económico bastante semejante, en lo que concierne al principal destino mercantil externo de la producción. Para los vicentinos fue, primero, la región azucarera del nordeste del Brasil y, después, la aurífera de las Minas Gerais; para los misioneros, primero la región minera andina y, después, los centros portuarios y mercantiles de la plata.

\footnotetext{
${ }^{25}$ José L. Olaizola, Bartolomé de Las Casas, crónica de un sueño, Colección Memoria de la Historia 57, 3a. ed. (Barcelona: Editorial Planeta, 1992), 131 y 132.
} 
El conflicto recurrente entre los dos fenómenos, que duró en cuanto subsistió la Unión Ibérica, tuvo características especiales, a la vez que tenía matices de conflicto internacional (España versus Portugal) y de conflicto interétnico (paulistas versus guaraníes). Fue, de facto, una guerra civil entre súbditos de un mismo soberano. Esto se debió, entre otras cosas, al pacto de las Cortes de Tomar, cuando Felipe II de España fue aceptado como soberano del reino de Portugal. La aceptación de un Habsburgo en el trono portugués fue admitida en la medida que, entre otras cosas, hubo un compromiso para mantener a los lusitanos en los puestos de administración del reino y de las colonias. Con esto, las dos naciones mantuvieron una fuerte identidad individual, a pesar de la unión personal que las ataba.

Los bandeirantes buscaban apresar indios para convertirlos en esclavos y los jesuitas intentaban impedir que esto ocurriera en su órbita de influencia. Estaba planteado el conflicto. Las regiones misioneras guaraníes iban a mantenerse como uno de los puntos principales de las discordias sobre límites entre las Coronas ibéricas en Suramérica, a lo largo de dos siglos y, posteriormente, entre las jóvenes naciones independientes suramericanas.

Este tipo de dicotomía fue observado incluso entre los portugueses, teniendo como objeto de discordia la misma cuestión de la esclavización de los indígenas. Fue el caso de la Insurrección de Beckman, que enfrentó a colonos y padres jesuitas en el norte de Brasil, en 1682, cuando ya se había terminado la Unión Ibérica.

De igual manera, la confrontación entre encomenderos y protectores de indios (casi siempre religiosos) en la América española muestra tres puntos de vista diferentes acerca de los indígenas: primero, la posición de los colonos, empresarios o terratenientes, que los veían como fuerza de trabajo; segundo, la posición de los religiosos en general, que los veían como almas que debían salvarse o preservarse; finalmente, la posición oficial y burocrática, que los veían como súbditos diferenciados, con potencial para convertirse en fuerza de trabajo o efectivos militares: "El desarrollo de las Misiones, que sorprendió hasta a la propia Compañía de Jesús, inquietó a los colonizadores españoles, que ya se venían enfrentando a los padres por la apropiación de la fuerza de trabajo indígena" 26 .

Las dos primeras posiciones, tanto en la órbita portuguesa como en la órbita española fueron defendidas, franca y abiertamente, por las partes interesadas. La posición oficial-burocrática, mientras tanto, tendía a mantenerse como algo muy delicado y de difícil aplicación. La cuestión que estaba en juego era la del mantenimiento e integridad de los imperios coloniales ibéricos. Para esto era necesario tener el apoyo de colonos, padres e indígenas. En otras palabras, se debía

\footnotetext{
26 "O desenvolvimento das Missões, que surpreendeu até a própria Companhia de Jesus, inquietou, porém, os colonizadores espanhóis, já em luta com os padres pela apropriação da força de trabalho indígena”. Bandeira, $O$ expansionismo, 27.
} 
sostener la autoridad metropolitana sobre una base fragmentada, cuyas partes poseían pocos intereses comunes y muchos intereses divergentes ${ }^{27}$.

Este hecho se agudizó en las reducciones de indios guaraníes. Allí los intereses de los encomenderos enfrentaban la fuerza creciente de la Compañía de Jesús en Europa y en América. Sin embargo, legalmente, los padres no podían cuestionar el derecho de los hacendados a la encomienda. Tampoco podían evitar las requisiciones de reclutamiento forzado que hacían las autoridades coloniales en tiempos de guerra o de conflictos inminentes. Existía, de este modo, en el mundo "guaraní-misionero", una frágil y delicada línea de tensión que equilibraba objetivos opuestos.

La diferenciación de este universo social "guaraní-misionero", en relación con el resto de las colonias del continente, puede ser entendida, en este contexto, casi como si fuera un cuerpo extraño entre los cuadros característicos del sistema colonial. Si las fuerzas hegemónicas presentes en la América ibérica actuaban en el sentido de reforzar el sistema colonial, y esta es una premisa plenamente aceptable, entonces, la tentativa de eliminación de este modus vivendi diferente e inadecuado iba a ponerse en marcha, tarde o temprano.

Evidentemente, como señala Clovis Lugon, "el mundo colonial de manera alguna aceptaba y no podía aceptar la existencia de esas comunidades indígenas libres" y no escatimó esfuerzos para suprimirlas; primero, permitiendo o incentivando la obra de depredación que emprendían los bandeirantes, coadyuvada con igual violencia y crueldad por los encomenderos; después, uniéndose los portugueses con los españoles en operaciones militares conjuntas para destruir definitivamente la República Guaraní, con el pretexto de la ejecución del Tratado de Límites, firmado en 1750 por los gobiernos de Lisboa y Madrid ${ }^{28}$.

A esto hay que agregar el hecho de que las reducciones indígenas quedaran, en su mayoría, ubicadas geográficamente en los límites de las expansiones coloniales portuguesas y españolas, tornándolas objeto de preocupación considerable en cualquier plan de ataque o defensa militar. Semejantes cuidados fueron una constante al final del periodo de la Unión Ibérica ${ }^{29}$.

\footnotetext{
${ }^{27}$ En verdad, sin la colaboración de las fuerzas y de los agentes presentes en el universo colonial, toda la estructura se podría desmoronar, pues no existían condiciones económicas ni demográficas que permitieran a las metrópolis ibéricas sostener la soberanía colonial solamente a través de la tutela militar.

${ }^{28}$ El autor escribe en un estilo narrativo, por lo cual induce al lector a imaginar una conspiración luso-hispánica contra una supuesta "República Guaraní". Puede ser una simple consecuencia estilística o una intención objetiva, pero de cualquier manera resulta exagerada. "Evidentemente, como Clovis Lugon salientou, "o mundo colonial de maneira alguma aceitava e não podia aceitar a existência dessas comunidades indígenas livres" e não poupou esforços para suprimi-las; primeiro, permitindo ou incentivando a obra de depredação, que os bandeirantes empreenderam, coadjuvada com igual violência e crueldade pelos encomenderos; depois, unindo-se portugueses e espanhóis em operações militares conjuntas, para esmagar, definitivamente, a República Guarani, a pretexto da execução do Tratado de Limites, firmado, em 1750, pelos Governos de Lisboa e de Madri”. Bandeira, O expansionismo, 27 y 28.

${ }^{29}$ Sobre el papel fronterizo de las reducciones religiosas, ver John Hemming, "Os índios e a fronteira no Brasil colonial”, en Leslie Bethell, História da América Latina: América Latina Colonial, 2 vols. (São Paulo: Ediusp; Brasília: Fundação Alexandre de Gusmão, 1999), 2: 423-470.
} 
La cohesión y organización interna de los Treinta Pueblos estuvieron también vinculadas a su situación fronteriza. La seguridad colectiva de estas poblaciones misioneras, uno de los frentes de colonización ibérica, solamente se logró plenamente cuando se organizó un ejército, que actuó como escudo permanente de la frontera más expuesta del imperio colonial español en América del Sur ${ }^{30}$.

Después de veintisiete años de lucha, la Guerra de Restauración, comenzada en 1640, llegó a su final en Portugal. A partir de 1668 la corte de Lisboa empezó a tener un mayor interés por sus territorios suramericanos. El establecimiento de los límites entre las colonias lusitanas e hispánicas, sin embargo, permaneció abierto. El ya ineficaz Tratado de Tordesillas se convirtió oficialmente en letra muerta, como consecuencia de la deflagración entre las dos naciones que lo habían firmado.

Terminada la Guerra de Restauración, dos grandes tareas nacionales se imponían inmediatamente a los portugueses. Evitar o contener una nueva embestida militar española y continuar la colonización del Brasil. Además, durante toda la guerra, el Brasil fue la fuente más caudalosa de recursos. Sobre todo a través de la producción azucarera. Con estos recursos se fomentaron apoyos y se disiparon hostilidades. Una conspiración internacional favoreció las armas portuguesas durante aquellos 27 años de guerra. Pero, más de una vez, se habían puesto en relieve las dificultades resultantes del estrecho hinterland metropolitano portugués. Por lo tanto, surgió la idea de una metrópolis portuguesa instalada en tierras brasileras, cuyo interior era prácticamente inexpugnable y donde sería fácil amenazar las fuentes de riqueza ultramarina del reino vecino, en términos de retaliación, por cualquier desacato sufrido en Europa ${ }^{31}$.

El periodo entre el final de la Guerra de la Restauración en Portugal y el comienzo de la Guerra de Sucesión en España, continuó sin que hubiera enfrentamientos explícitos entre las naciones ibéricas en Europa (1667 a 1701). En el Nuevo Mundo, sin embargo, el año 1680 marcó el inicio de una nueva etapa de enfrentamientos de carácter exclusivamente colonial. Fue en este

\footnotetext{
30 “A coesão e a organização interna dos Trinta Povos estão também vinculadas à sua situação fronteiriça. A segurança coletiva destas povoações missionárias, numa das frentes de expansão da colonização ibérica, somente se encontrou plenamente realizada quando se organizou um exército, escudo permanente na fronteira mais exposta do império colonial espanhol na América do Sul”. Arno Kern Alvarez, Missões: uma utopia política, Série Documenta 14 (Porto Alegre: Mercado Aberto, 1982), 262.

31 "Finda a Guerra da Restauração, duas grandes tarefas nacionais se impunham imediatamente aos Portugueses. Evitar, ou conter uma nova investida militar espanhola e prosseguir na colonização do Brasil. Aliás, durante toda a guerra, o Brasil a fonte mais caudalosa de receitas. Sobretudo através da produção açucareira. Com essas receitas se fomentaram apoios e se dissiparam hostilidades. A conjuntura internacional favorecera as armas portuguesas durante aqueles 27 anos de guerra. Mas, mais uma vez, eles tinham posto em relevo as dificuldades resultantes do estreito hinterland metropolitano português. Aflorou então a idéia da solidez de uma metrópole portuguesa instalada em terras brasileiras, cujo interior era praticamente inexpugnável e donde se tornaria fácil ameaçar as fontes de riqueza ultramarina do reino vizinho, em termos de retaliação, por qualquer desacato sofrido na Europa". Martínez, História, 159-160.
} 
año que D. Manuel Lobo, encargado de una expedición, fundó en la orilla septentrional del río de la Plata la ciudadela de Colônia do Santíssimo Sacramento.

El establecimiento portugués quedaba en un lugar próximo de Buenos Aires, hacia el norte. La posición seleccionada fue demasiado desafiante como para que permaneciera sin una respuesta porteña. Dicha respuesta fue firme y desalojó a los lusitanos en aquel mismo año. Los hechos que tienen que ver con la fundación, pérdida y posteriores ataques a aquella fortificación fueron motivo de exhaustivos esfuerzos historiográficos. De esta experiencia surgieron las más variadas hipótesis, entre las cuales cabe destacar, primero, la idea de que existía una noción de "espacio vital", desarrollada en el seno de la política estatal portuguesa; segundo, la idea de una percepción prematura del valor de los campos orientales, especialmente en cuanto a la explotación del ganado cimarrón; $y$, tercero, la existencia de una fuerte competencia en torno al comercio ilícito $^{32}$ con las otras colonias españolas de Suramérica, especialmente la región minera de Potosí.

La construcción de la fortaleza de Colonia no fue, sin embargo, un hecho aislado. Hacía parte de la secular práctica portuguesa de garantizar su expansión territorial a partir del establecimiento de plazas fortificadas o presídios. En general, ejercían también el papel de factorías comerciales. En Suramérica, además de Colonia, también fue importante el ejemplo del Real Forte Príncipe da Beira, el cual garantizó el avance territorial portugués hacia el oeste, al sur del trazado del río Amazonas ${ }^{33}$.

Esta fue una de las estrategias desarrolladas para mantener un imperio colonial, a la luz de una metrópolis que, al comienzo de su proceso de expansión, tenía aproximadamente un millón y medio de habitantes y que, por lo tanto, carecía de las condiciones para suministrar una gran multitud de brazos para su misma empresa colonial. Esta escasez forzaba fácilmente la opción militar y geopolítica para mantener una presencia oficial más agresiva, pero solamente en determinados puntos clave que garantizaran áreas de mayor interés para la Corona.

Las características del litoral Atlántico, al sur de Laguna ${ }^{34}$, hacia el río de la Plata, favorecía aun más esta praxis. Considerado el litoral en línea (sin bahías) más largo del mundo, sigue sin cortes significativos, exceptuándose la hoz de la laguna de los Patos (barra del Rio Grande). Igualmente la orilla atlántica, al norte del río de la Plata, sigue este mismo modelo geográfico, con las excepciones de la bahía de Montevideo y de la bahía de Maldonado. Con esto, al

\footnotetext{
${ }^{32}$ Esta tercera hipótesis no va a ser objeto de explicación específica en este texto, pues puede ubicarse junto con las otras cuestiones económicas. Para un acercamiento al tema, se pueden consultar: Guilhermino Cesar, $O$ contrabando no sul do Brasil (Caxias do Sul y Porto Alegre: Universidade de Caxias do Sul; Escola Superior de Teologia São Lourenço de Brindes, 1978) y Emanuel Soares da Veiga, O comércio ultramarino espanhol no Prata, Coleção Khronos 13 (São Paulo: Editora Perspectiva, 1982).

${ }^{33}$ Esta praxis fue llevada al Brasil, a partir de experiencias previas de los portugueses en África y Asia. Los orígenes de las colonizaciones lusitanas se sustentaron más a partir de sus asentamientos que por una interiorización territorial (por ejemplo: las factorías y plazas fortificadas de África y Asia).

${ }^{34}$ Hoy, ciudad de Santa Catarina, Brasil.
} 
protegerse adecuadamente estos puntos, se podía garantizar con más facilidad el dominio de la gran planicie que existe desde allí hasta la sierra Geral y las elevaciones vecinas al río Ibicuy ${ }^{35}$.

Los líderes que iban a involucrarse en las innumerables guerras y revoluciones, en tierras -hoyuruguayas, aprendieron pronto que era una necesidad imprescindible controlar el litoral platino, especialmente Montevideo, para que fuera posible lograr la victoria. La idea de que la corte de Lisboa divisaba la orilla norte del río de la Plata como uno de los límites de su espacio vital, también descrito como "frontera natural", en sus dominios en Suramérica, fue planteada por muchos intelectuales, en una tentativa de reinstituir una organicidad geográfica al estudio de un periodo en el cual era difícil defender la idea de una nacionalidad autónoma y genuinamente brasileña:

Aunque es verdad que, como registran los viejos mapas, desde los primeros tiempos de la colonización Portugal exageraba en el estuario el límite meridional de sus dominios, no por eso tiene sentido interpretar la fundación de Colonia desde el punto de vista de la organicidad de un territorio nacional que en esta época no existía. Pero esta es la trayectoria seguida por el discurso geográfico del nacionalismo, que identifica en el Río de la Plata una "frontera natural" de la entidad luso-brasilera en América ${ }^{36}$.

La confusión entre las expresiones frontera natural y espacio vital puede buscarse, justamente, en la correspondencia diplomática portuguesa, en la cual frontera natural aparece constantemente, sobre todo para justificar posiciones ventajosas de Portugal. La expresión marcos visibles es, de la misma manera, recurrente y siempre con el mismo significado de frontera natural, lo que explica con más claridad su significado, es decir, el intento por dirimir dificultades de identificación de límites, especialmente en fronteras secas. Si este fuera, de hecho, el origen del tránsito entre las expresiones, entonces se caería en un error, pues siempre que aparece en la documentación está desprovista de la noción de espacio vital, propia del periodo del ochocientos y los años posteriores

\footnotetext{
${ }^{35}$ Hoy, Rio Grandedo Sul, Brasil.

36 "Se é verdade que, como registram os velhos mapas, desde os primeiros tempos da colonização Portugal enxergava no estuário o limite meridional dos seus domínios, nem por isso faz sentido interpretar a fundação de Colônia do ponto de vista da organicidade de um território nacional que, à época, não existia. Mas essa é a trajetória seguida pelo discurso geográfico do nacionalismo, que identifica no Rio da Prata a "fronteira natural" da entidade luso-brasileira na América”. Demétrio Magnoli, O corpo da pátria: imaginação geográfica e política externa no Brasil (São Paulo: Editora da Universidade Estadual Paulista-Moderna, 1997), 71. Obsérvese también la expresión literalmente utilizada por Assunção: "Si hasta ahora nos referimos a la presencia portuguesa en el Plata en forma genérica y en especial al llamado proceso paulista, más que necesario resulta imprescindible dedicar un particular paréntesis a la tan controvertida población y puesto militar fortificado que los lusitanos fundaron en 1680, con la pretensión de fijar definitivamente sus límites en lo que ellos mismos llamaban 'la frontera natural'”. Fernando O. Assunção, El gaucho - Estudio socio-cultural, 2 tomos (Montevideo: Dirección General de Extensión Universitaria-División Publicaciones y Ediciones, 1978), 1: 164.
} 
Es muy difícil establecer en qué grado los portugueses y los españoles conocían las riquezas pecuarias de los campos orientales ${ }^{37}$. La riqueza existía y había aumentado desde el tiempo de su introducción, en el siglo XVI. El ganado chimarrão (cimarrón) eran animales que, descendientes de individuos domesticados, nacieron libres y volvieron a una forma de existencia salvaje. Su proliferación fue rápida, incluso asombrosa, habiéndose adaptado plenamente al nuevo ecosistema.

Elementos de atracción, además de un sentimiento de afirmación política, serían por cierto los densos rebaños huidos que poblaban estas campiñas, originarios de la simiente aquí lanzada por los jesuitas españoles en el tiempo de su primera tentativa de catequización de las gentes que vivían en el margen oriental del Uruguay y que vivían ahí en grupos errantes. El otro origen del ganado aquí introducido, particularmente el mular y el caballar, fueron sin duda los contingentes desembarcados en el margen superior del Río de la Plata por Hernandarias de Saavedra antes de subir a la confluencia del gran estuario para asumir el gobierno del Paraguay ${ }^{38}$.

La comprensión exacta del grado de percepción del potencial regional que tenían las fuerzas coloniales ibéricas en contacto en el Plata es fundamental para que se establezca en qué grado los intereses económicos de los diferentes grupos influyeron el proceso de ocupación europea ${ }^{39}$ en la orilla izquierda del río Uruguay. De hecho, la antinomia presente en la historiografía que trata del tema se muestra, de un lado, por los que asumen un ángulo de observación economicista y, por otro lado, los que defienden un análisis de tipo geopolítico. Tal discusión es, aparentemente, retórica y refleja más la defensa de paradigmas de observación de fenómenos históricos que un intento más objetivo y cauteloso de aproximación a la realidad. En verdad, los eventos y los procesos que pueden recuperarse de este fenómeno de ocupación, indican la coexistencia de ambas las motivaciones.

Hubo políticas de Estado muy claras, que demuestran una intención de ampliación de soberanías. La historiografía contemporánea consagró este tipo de actitud política en la expresión "imperialismo". Las naciones involucradas, sin embargo, eran monarquías absolutistas y, como tales, eran extremamente verticales en el aspecto meramente formal de su

\footnotetext{
37 Sobre la noción de potencialidad económica de la región en aquel periodo, ver Oliveira Viana, Populações meridionais do Brasil, "O Campeador Rio-Grandense" (Rio de Janeiro: Paz e Terra, 1974), 2: 40 y 41 . Ver también Assunção, El gaucho, 1: 18.

38 "Elementos de atração, afora o sentimento de afirmação política, seriam por certo os densos rebanhos alçados que povoavam estas campanhas, originários da semente aqui lançada pelos jesuítas espanhóis ao tempo de sua primeira tentativa de catequese do gentio que demorava à margem oriental do Uruguai e aí vivia em bandos errantes. Outra origem do gado aqui introduzido, particularmente o muar e o cavalar, foram sem dúvida os contingentes desembarcados na margem superior do Rio da Prata por Hernandárias de Saavedra, antes de subir os confluentes do grande estuário para assumir o governo do Paraguai”. Moysés Vellinho, Capitania d'El Rei: aspectos polêmicos da formação Rio-Grandense, 2a. ed., Coleção Província (Porto Alegre: Editôra do Globo, 1970), 11.

${ }^{39}$ En el sentido del origen étnico del proceso de ocupación. El término se usa de acierdo con la definición encontrada en la documentación de la época, donde no hay distinción entre el portugués y el español, en el sentido de que sea inmigrante o de que sea criollo.
} 
estructura política y esta perspectiva no puede perderse, bajo pena de comprometer todo el estudio de los fenómenos que involucran fronteras nacionales en este periodo.

La figura del monarca pretendía ser la amalgama que unía la nación, pero, curiosamente, un individuo podía hacerse soberano de más de un Estado y, por tanto, el principal mentor de sus políticas, debido a la estructura vertical del Antiguo Régimen. Los grupos en disputa por el poder en la Europa moderna, según esta lógica, reflejaban más las relaciones de familia, o incluso de bloques de noblezas y aristocracias, con una alta tendencia a la internacionalización, que intereses puramente nacionales.

El poder político fue la joya, el premio deseado. La fuente principal de prestigio y reconocimiento. Las acciones de los principales agentes, aquellos con un grado más elevado de influencia social, eran determinadas por relaciones que involucraban estructuras de poder político, antes que por intereses económicos. Este patrón persistió, en grado más grande o más pequeño, hasta el advenimiento de las democracias liberales, cuando, por principio, "uno cualquiera" pasaba a tener acceso al poder político del Estado y la diferencia social determinante pasó a otro nivel: la capacidad de acumular riquezas.

Sin embargo, hay un tipo de fuerza social permanentemente presente donde quiera que haya personas viviendo en sociedad, y es la necesidad de aquellos productos requeridos para la manutención de la existencia humana. En esto sobrevive y con vigor el argumento economicista y, en este sentido, no puede ser negado o alejado de cualquier estudio histórico más amplio.

Existieron, entonces, en esta lógica, intereses económicos específicos que determinaron el proceso no oficial y no estatal de ocupación del territorio al norte del río de la Plata. Los agentes pioneros, bajo esta óptica, fueron los contrabandistas, los arreadores, los coramberos y otros expertos en vivir en la campiña platina, que adoptaron estos estilos de vida y actividades como opción de subsistencia económica. Fueron genérica y despreciativamente llamados gauchos. Sinónimo, en general, de bandoleros, gamberros, aventureros y, principalmente, gentes de la campiña:

El gaucho cambió enormemente a través de dos siglos de practicar la cacería y el cuidado del ganado, y su nombre se alteró considerablemente también. Los oficiales del gobierno usaban el término gauderio en 1746 y gaucho en 1774 para describir a los hombres que mataban ilegalmente ganado para obtener cuero y sebo en la frontera pampeana. Un término sinónimo, changador, aparece tempranamente en los documentos del cabildo, o concejo municipal, de Buenos Aires en 1729. El changador, a menudo un peón que trabajaba por su cuenta matando ganado y comercializando cueros sin la licencia o acción requerida, puede considerarse como el precursor individual de aquellos que luego conformaron un 
grupo social con valores distintivos y un estilo de vida ecuestre: los gauchos de la frontera del Río de la Plata ${ }^{40}$.

También:

El nacimiento del gaucho está condicionado por una cultura augural, consecuencia de un hábitat, conjunción de grupos étnicos nativos, características de la colonización europea (hispana y portuguesa), razones geopolíticas, y otros varios etcéteras, [...], pero, por sobre todo, consecuencia de la introducción de los ganados mayores que se volvieron cimarrones o alzados, en unos territorios semivacíos y cuasimarginales o fronterizos, e introducidos antes del hombre, es decir antes de la efectiva colonización de esas tierras. Y es esta cultura augural la que transforma al colono, hispano o portugués, a sus hijos criollos, a muchos de los indígenas, y a otros tantos hombres de los más diversos orígenes, que se integran al hábitat, hábitat que resulta centro geográfico de esa misma cultura, en elementos aparentemente negativos para las rígidas estructuras coloniales, pero social y económicamente imprescindibles para las mismas $\mathrm{y}$, especialmente, los hace protagonistas, verdaderos ejes motores, de esa misma cultura y de esa sociedad, que debiendo amarlos y preferirlos, los negó hasta el enronquecimiento, cometiendo el pecado de Pedro ${ }^{41}$.

Es posible notar, de esta manera, dos movimientos distintos en cuanto a su naturaleza, pero interdependientes y con fuerte influencia mutua en lo que concierne a los intereses de expansión de soberanías. En otras palabras, en la tentativa permanente de ubicar la frontera "un poco más para allá" es indiscutible que los intereses de tipo más geopolítico fueron los pioneros. Los esfuerzos oficiales de los españoles en el siglo XVI, comenzando por Asunción, en las orillas del río Paraguay, siguiendo el curso del río Paraná y culminando en Buenos Aires, en el Plata; y de los portugueses, iniciando en el siglo XVII con el litoral sur de Santa Catarina y, en un salto formidable, con Colonia do Santíssimo Sacramento, son una prueba de esto.

La restauración en Portugal (1640) y la fundación, destrucción y restitución de Colonia (16801681), trajeron un grave problema diplomático que las naciones ibéricas no trataron seriamente sino hasta 1750, con el Tratado de Madrid. La cuestión de la ocupación lusitana de tierras reclamadas por la Corona española y la inviabilidad política de su devolución por parte de Portugal, sumada a una similar inviabilidad política de su entrega pura y simple por parte de

\footnotetext{
40 "The gaucho changed greatly over the course of two centuries of hunting and tending livestock, and his name was considerably altered as well. Government officials used the term gauderio in 1746 and gaucho in 1774 to describe men who illegally killed cattle for hides and tallow on the pampean frontier. A synonymous term, changador, appeared earlier in documents of the Buenos Aires cabildo, or town council, in 1729. The changador, often an enterprising peon who went into business for himself by killing and marketing hides, without the required license, or acción, might be considered the individual precursor of those who later developed into a social group with distinctive values and an equestrian lifestyle: the gauchos of the Río de la Plata frontier". Richard W. Slatta, Gauchos and the Vanishing Frontier (Lincoln: University of Nebraska Press, 1992), 9.

${ }^{41}$ Assunção, El gaucho, 1: 16.
} 
España, iba a convertir las fronteras entre las dos Américas en un asunto delicado entre las dos cortes y de difícil trato para las autoridades coloniales.

El espacio sudamericano pasará a ocupar una posición privilegiada en los temas nacionales e internacionales que preocupaban a las cortes europeas:

El desarrollo económico del Brasil no constituyó solamente una fuente de financiamiento de los gastos realizados por la diplomacia portuguesa del siglo XVIII. Fue también la base de toda la política externa de Portugal, cuyo prestigio y capacidad de negociación dependían, en gran medida, de ese mismo desarrollo. Es significativo que las instrucciones de los diplomáticos acreditados en Lisboa les encargaban persistentemente indagar sobre el valor del comercio del Brasil y las ganancias que quedaban para la corona portuguesa (cf., por ejemplo, SaintAymour, Recueil des instructions données aux ambassadeurs et ministres de France - Portugal, 167, 262, 328). Y examinando los informes de los diplomáticos ingleses acreditados en Lisboa en los siglos XVII y XVIII, percibimos fácilmente la importancia que tenia para ellos la llegada de las flotas del Brasil (cf. Descriptive List of the State Papers Portugual 1661-1780) ${ }^{42}$.

Se destaca, principalmente, el crecimiento de un conjunto de relaciones regionales, a veces clandestinas como el contrabando, aunque a veces de carácter diplomático. Paro aun estas últimas, más oficiales, tenían un carácter provisional, debido a la distancia con los principales centros de poder.

Los actos de las autoridades coloniales dependían, por regla general, de la aprobación de las respectivas cortes metropolitanas, especialmente cuando tenían el efecto o la naturaleza de relaciones internacionales de cualquier género. Al darse cuenta de que entre la comunicación y el recibimiento de la respuesta metropolitana de un acto cualquiera podía transcurrir un lapso de varios meses y hasta años, se percibe el origen de este carácter provisional.

Los hechos y los eventos, sin embargo, exigían muchas veces una respuesta inmediata y enérgica por parte de aquellas mismas autoridades coloniales, las cuales, no siempre apoyadas por el vasto conjunto de normas e instrucciones que orientaban sus actividades, necesitaban

\footnotetext{
42 "O desenvolvimento económico do Brasil não constitui apenas a fonte do financiamento das despesas realizadas com a diplomacia portuguesa do século XVIII. Foi também base de toda a política externa de Portugal, cujo prestígio e capacidade de negociação dependiam, em larga medida, daquele mesmo desenvolvimento. É significativo que as instruções aos diplomatas acreditados em Lisboa persistentemente lhes cometessem a indagação do valor do comércio do Brasil e dos lucros que dele adviriam para a coroa portuguesa (cf., por exemplo, Saint-Aymour, Recueil des instructions données aux ambassadeurs et ministres de France - Portugal, 167, 262, 328). E percorrendo os relatórios dos diplomatas ingleses acreditados em Lisboa, nos séculos XVII e XVIII, apercebemo-nos facilmente da importância que para eles tinha a chegada das frotas do Brasil (cf. Descriptive List of the State Papers Portugual 1661-1780)". Martínez, História, 175.
} 
operar sin autorización previa. Este tipo de diplomacia marginal ${ }^{43}$ ganó espacio en la medida en que los puntos de contacto luso-hispánicos se fueron estrechando en la región platina, con más énfasis a partir de 1680. Este tipo de relación diplomática se ha mostrado duradera en el Plata, aun después de que aparecieran los Estados independientes en Suramérica.

La Colonia del Sacramento fue fundada en 1680, tras una empresa oficial portuguesa previamente proyectada. Los eventos relativos a aquella localidad, desde su fundación hasta su entrega definitiva a España en 1777, han sido objeto de estudio de innumerables trabajos de historia platina ${ }^{44}$.

La construcción de la fortaleza se inició el 26 de enero de 1680, por orden del príncipe regente don Pedro ${ }^{45}$. Para esta tarea se usaron 300 soldados de tropa de línea del ejército portugués, bajo el mando de don Manuel Lobo, entonces gobernador de Rio de Janeiro. Estaba ubicada en la orilla izquierda (septentrional) del río de la Plata, prácticamente frente a la ciudad de Buenos Aires, en la otra orilla del mismo río. Este hecho debió provocar un profundo y aterrador impacto en las autoridades porteñas, principalmente porque iba a permanecer como el establecimiento portugués más cercano a un puerto marítimo español en América:

Un día, al rayar el año de 1680, andaba el marinero Marcos Román, de Buenos Aires, bordeando las islas fronterizas en busca de leña, cuando lo sorprende una cosa que lo hace retornar sobresaltado al burgo porteño. El marinero salta en tierra botando el alma por la boca y va directo a las autoridades. Necesitaba darles sin demora una grave noticia: cinco chalupas portuguesas habían llegado a la otra margen del río, justo al frente de la plaza castellana ${ }^{46}$.

La expedición debía hacerse con rapidez y sigilo, según recomendaciones de las autoridades metropolitanas ${ }^{47}$. Tales objetivos, sin embargo, no fueron logrados plenamente, pues la presencia portuguesa fue rápidamente identificada y la reacción española fue veloz y enérgica: unos meses después, 250 soldados y 300 indios de las misiones, bajo la autoridad del gobierno de Buenos Aires, asaltaron Colonia y convirtieron el sitio en ruinas ${ }^{48}$.

\footnotetext{
${ }^{43}$ El concepto de diplomacia marginal, es decir, aquella realizada entre agentes de relaciones internacionales que no necesariamente expresan o han pasado por la revisión previa de la posición oficial de un gobierno nacional soberano, es utilizado, entre otros autores, por Reckziegel (1997).

${ }^{44}$ Sin tener en cuenta el periodo de dominación luso-brasileña de la banda oriental del Uruguay, entre 1816 y 1828.

${ }^{45}$ Hermano del rey Afonso VI. En un golpe de Estado en 1667, don Pedro alejó al rey y asumió la regencia. Con la muerte de Afonso VI, ascendió al trono en 1683.

46 "Um dia, mal raiara o ano de 1680, andava o marinheiro Marcos Román, de Buenos Aires, bordejando as ilhas fronteiras em busca de lenha, quando o surpreende qualquer coisa que o faz retornar com sofreguidão ao burgo portenho. $\mathrm{O}$ marinheiro salta em terra botando a alma pela bôca e vai direto às autoridades. Precisava dar-lhes sem demora uma grave notícia: cinco chalupas portuguêsas tinham arribado à outra margem do rio, bem defronte à praça castellana". Vellinho, Capitania, 21.

${ }^{47}$ Recomendación del Consejo Ultramarino, en Lisboa: "com tanta gente e segrêdo que quando soubessem já estivesse pronta para a defesa”. La indicación documental es de Aurélio Porto, apud Vellinho, Capitania, 27.

${ }^{48}$ Bandeira, $O$ expansionismo, 56. Todo el capítulo III de esta obra, así como el final del capítulo II, contienen información y análisis más detallados sobre la cuestión de Colônia do Sacramento.
} 
En el campo diplomático, los portugueses lograron la breve recuperación de la posición perdida" ${ }^{49}$, restituida por el Tratado Provisional, celebrado en 7 de mayo de 1681: "Los gobiernos de las dos metrópolis entraron luego en contacto y el rey de España [...] procuró acomodar las cosas" $" 50$. La cuestión de los límites de Tordesillas volvió a la escena en este mismo acuerdo, pero con la novedad de la instalación de una comisión bilateral para tratar el caso. Francisco de Paula Cidade cita a Pandiá Calógeras, sobre las dificultades de esta comisión:

Los españoles, que cuando se trataba de las Molucas, es decir, del Oriente, argumentaban que las leguas debían contarse comenzando por la isla más occidental de las de Cabo Verde (San Antonio), alegaban ahora que la cuenta debía hacerse a partir de la más distante, la de la Sal. Portugal argumentaba al contrario, con la misma inconsistencia con respecto a lo que antes había dicho ${ }^{51}$.

Por veinticuatro años, a partir de la primera devolución, Colonia del Sacramento permaneció bajo bandera portuguesa. La situación diplomática de Europa, así como de la metrópoli lusitana, sufrió grandes cambios a finales del siglo XVII, culminando con la Guerra de Sucesión Española (1701). La cuestión se convertía, una vez más, en una disputa política típicamente moderna entre bloques hegemónicos, identificados con casas nobles: Austrias versus Borbones.

En esta guerra, de proporciones continentales, fueron establecidas las bases que llevarían a las dos principales potencias a disputar la hegemonía europea hasta, por lo menos, mediados del siglo XIX: Francia e Inglaterra. A lo largo del siglo XVIII las naciones ibéricas fueron adaptándose a los nuevos tiempos y asumieron alineamientos distintos, de acuerdo con sus intereses, con las dos potencias en ascenso. En cuanto Portugal reafirmaba los seculares lazos diplomáticos con Inglaterra, España, que ya era borbónica, estrechaba los lazos de familia con Francia. Semejante cuadro apuntaba hacia un estado de tensión permanente, que iba a culminar con la guerra de 1801 y la posterior invasión de Portugal en 1807.

En la Guerra de Sucesión Portugal tuvo una estrecha posibilidad para realinear y reorganizar su política exterior, en el sentido de garantizar posiciones más favorables en el escenario

\footnotetext{
${ }^{49}$ Las autoridades portuguesas desarrollaron una fuerte acción de propaganda internacional que constó, incluso, de publicaciones de libros y libelos, mediante los cuales se buscaba mostrar una supuesta bona fide lusitana en oposición a una acción violenta de España. Ver Miguel Frederico do Espírito Santo, O Rio Grande de São Pedro entre a fé e a razão: introdução à história do Rio Grande do Sul (Porto Alegre: Martins Livreiro, 1999), 73 y 74.

50 "Os governos das duas metrópoles entraram logo em contacto e o rei de Espanha [...] procurou acomodar as cousas". Francisco de Paula Cidade, Lutas, ao Sul do Brasil, com os espanhóis e seus descendentes (1680-1828), Biblioteca Militar, vols. CXXVII y CXXVIII (Rio de Janeiro: Ministério da Guerra, 1948), 30. Ver, también, Espirito Santo, O Rio Grande, 74.

51 "Os espanhóis, que quando se tratava das Molucas, isto é, do oriente, sustentavam que as léguas deviam contar-se a começar pela ilha mais ocidental das do Cabo Verde, pela de Santo Antonio, alegavam agora que a conta devia ser a partir da mais distante, da do Sal. Portugal sustentava o contrário, com igual inconseqüência do que antes havia dito". Cidade, Lutas, 30.
} 
internacional. Primero, intentando alinearse con los Borbones, en una actitud considerada insólita $^{52}$ e inesperada, que resultó en el reconocimiento del pretendiente francés al trono español, Felipe V, por el tratado del 18 de junio de 1701.

Sin embargo, a pesar de su intento por crear un espacio diplomático propio e independiente, al que debe sumarse el factor de la política interna donde existía una división entre grupos profranceses y grupos pro-ingleses, Portugal no escapó de una proyección marginal en sus relaciones internacionales. La necesidad urgente empujó a aquella nación, en fin, a una aproximación más contundente con Inglaterra por el Tratado de Methwen, de 1703:

Francia no podía prestar tales ayudas y, en vista de eso, sucediendo los desastres militares franceses en Italia y en Reno, al mismo tiempo que la escuadra inglesa comandada por el almirante Safford andaba por las costas de Portugal, don Pedro II consideró nulos los tratados celebrados con Francia. Se pasó a una posición neutral, que Portugal aprovechó para rearmarse, con el objetivo de hacer respetar esta neutralidad o de entrar en beligerancia en condiciones satisfactorias. Desde finales de 1702 ya se consideraba en los medios diplomáticos que Portugal estaba dispuesto a adherir a la liga antifrancesa, habiéndole sido ofrecida como recompensa la incorporación en su territorio de las provincias gallegas $\mathrm{y}$ extremeñas. También le habían sido ofrecidas por los holandeses las Canarias y las Filipinas [...] Consecuentemente con el cambio de rumbo de la política de Lisboa, los generales franceses procuraban reunir medios para atacar a Portugal y temían un asalto portugués a Buenos Aires. Los temores franceses eran fundados, pues Portugal se alió con los ingleses, austriacos y holandeses a través de los tratados ofensivos y defensivos del 16 de mayo de $1703^{53}$.

La guerra en Europa fue, ciertamente, el pretexto que esperaban las autoridades coloniales españolas en el Plata para que pudieran librarse de la siempre incómoda presencia lusitana en Colonia del Sacramento ${ }^{54}$. El ataque y conquista españoles de aquella localidad se inició en

\footnotetext{
${ }^{52}$ Martínez, História, 178.

53 "A França não podia prestar tais socorros; e, em vista disso, sucedendo-se os desastres militares franceses na Itália e no Reno, ao mesmo tempo que a esquadra inglesa comandada pelo almirante Stafford andava pelas costas de Portugal, D. Pedro II considerou nulos os tratados celebrados com a França. Passou-se a uma situação de neutralidade, que Portugal aproveitou para rearmar-se; ou no sentido de ver respeitada aquela neutralidade ou no de passar à beligerância em condições satisfatórias. Desde finais de 1702 já se considerava ponto assente nos meios diplomáticos que Portugal estava disposto a aderir à liga antifrancesa, tendo-lhe sido oferecida como recompensa a incorporação no seu território das províncias galegas e estremenhas. Também the teriam sido oferecidas pelos Holandeses as Canárias e as Filipinas. [...] Em consequência da mudança de rumo da política de Lisboa, os generais franceses procuravam reunir meios para atacar Portugal; e receavam um assalto português a Buenos Aires. Os receios franceses eram fundados; pois Portugal se aliou aos Ingleses, Austríacos e Holandeses por tratados ofensivos e defensivos de 16 de Maio de 1703". Ibídem, 178 y 179.

${ }^{54}$ En un texto que puede situarse entre finales del siglo XVIII y 1803 , se percibe que nunca fue admitida la posesión portuguesa en la orilla izquierda del río de la Plata: "Veinticuatro años hicieron durar los portugueses en sus manos un depósito que según lo convenido debió durar cinco meses". Hubo una reclamación clara acerca del "uso y aprovechamiento del sitio, labores de sus ganados, madera, caza, pesca, y carbón como antes de que en él se hiciese
} 
1704 y fue completado en el año de 1705, bajo el comando de Alonso Valdés Inclán, gobernador de Buenos Aires, con órdenes superiores del virrey del Perú ${ }^{55}$.

Se devolvería Colonia a Portugal en la serie de tratados firmados en Utrecht, entre 1713 y $1715^{56}$. Los términos acordados fueron raros para el caso de Colonia, estableciendo una posesión más sobre un enclave que sobre un territorio, a la vez que el perímetro portugués en las orillas del río de la Plata iba a medirse por la marca inconstante determinada por un disparo de cañón ${ }^{57}$. En el año de 1716, el perímetro de Colonia y su fortaleza fueron entregados a los representantes portugueses ${ }^{58}$.

Pero más importante que esto, los tratados de Utrecht, tal y como fueron consagrados por la historiografía, abrieron una brecha consentida en la tradición de dos siglos que, bien o mal, aun estaba oficialmente sostenida por ambas Coronas.

Como ya fue mencionado, esta fue la última tentativa de configuración de las fronteras ibéricas alrededor del mundo y, en especial, en Suramérica, con soluciones exclusivamente de gabinete, de la misma manera como fue conducido el acuerdo provisional de 1681. Aun se esperaba una solución que siguiera los procedimientos decisorios que venían ocurriendo desde el Tratado de Alcáçovas, sin la necesidad de averiguar in loco las dificultades inherentes para que se trazaran efectivamente las fronteras.

La repetición del llamado a la mediación de la Santa Sede, que anterior a cualquier tratado de límites entre Portugal y España, fue el fenómeno pionero en el establecimiento de esferas de influencia entre la monarquía fidelíssima y la monarquía católica, se dio en el acuerdo de 1681, según el cual, si las comisiones negociadoras de las respectivas cortes fracasaban en la identificación de la verdadera línea de Tordesillas, el asunto debía irse al arbitrio del papado:

[...] y conviniendo de ambas potencias en nombrar comisarios en el término de dos meses que determinasen dentro de tres la controversia suscitada, y el de hacer de ocurrirse a Su Santidad en caso de discordia dentro de un año, quedó acabada la primera guerra al año siguiente de haberse comenzado ${ }^{59}$.

la población de la colonia". Anónimo, Noticias sobre el Río de la Plata: Montevideo en el siglo XVIII, Nelson Martínez Díaz, ed., Colección “Crónicas de América”, Historia 16 (Madrid: Información y Revistas, S.A., 1988), 55.

${ }_{55}$ Aquí existe una pequeña confusión de fechas en la historiografía. Reichel y Guttfreind dicen que fue en el año de 1703, a su vez, Ameghino y Birocco dicen que fue en el año de 1705. Heloísa J. Reichel e Ieda Guttfreind, As raizes históricas do Mercosul: a Região Platina colonial (São Leopoldo: Unisinos, 1996), 102 y Amado L. Cervo y Mário Rapoport, org., História do Cone Sul (Rio de Janeiro: Revan; Brasília: Editora Universidade de Brasília, 1998), 34. El cerco a la fortaleza se inició, de hecho, en octubre de 1704, como dice Flores y se terminó cinco meses después. Moacyr Flores, História do Rio Grandedo Sul (Porto Alegre: Nova Dimensão, 1997), 44.

${ }^{56}$ Soares, Fronteiras, 114.

${ }^{57}$ Fue costumbre hacer de ésta una medida estándar, incluso para fines de medición del mar territorial.

${ }^{58}$ Soares, Fronteiras, 130.

${ }^{59}$ Anónimo, Noticias, 55. 
Los indicios que demostraban que los tratados de Utrecht ya apuntaban a la superación de la línea de Tordesillas no fueron explícitos ni obvios. Paradójicamente, es el Tratado de Utrecht, firmado con los franceses el 11 de abril de 1713, el que indica con más fuerza este camino. Esto porque Colonia del Sacramento estaba muy cercana de la línea más occidental (la línea ideal portuguesa) atribuida al meridiano de Tordesillas, lo que la ponía en una región disputada, dentro de la lógica y de la esencia del tratado de 1493. En el tratado de 1713 no sucedía esto. Este último trataba de los límites en áreas hasta entonces no disputadas a la Corona española.

Su Majestad Cristianísima reconoce por el presente Tratado que las dos márgenes del Río de las Amazonas, así meridional como septentrional, pertenecen en toda propiedad, dominio y soberanía a Su Majestad Portuguesa y promete que ni ella ni sus descendientes, sucesores y herederos tendrán jamás ninguna pretensión sobre la navegación y uso del dicho Río, con cualquier pretexto que sea ${ }^{60}$.

La apertura de la cuestión amazónica entre los representantes de Portugal y los representantes de Francia fue, además de delicada, polémica, por las otras cuestiones que suscitaba. Por un lado, la intención de los negociadores fue simplemente la de limitar esferas de influencia francolusitanas, sin descartar los eventuales derechos de la monarquía española; y, por otro lado, la Francia de los Borbones, que estaban asumiendo el reino español, se convirtió en un remedo de portavoz de los intereses de la nación española. En todo caso, la Guerra de Sucesión española fue, principalmente, una guerra de Luis XIV.

La posición geográfica de Colonia, a pesar de la ventaja transitoria adquirida en Utrecht, era claramente insostenible en el largo plazo, si sobre ella decidieran caer los españoles. Teniendo en cuenta la necesidad de solucionar este problema logístico, los portugueses decidieron crear otros puestos-fortalezas a lo largo del litoral norte del río de la Plata, especialmente en el sitio y bahía donde hoy se encuentra Montevideo, en el año de 1723. Fue encargado de la tarea el Ajudante-de-Campo Manuel de Freitas Fonseca, pero resultó en un fracaso completo debido, nuevamente, a la rápida intervención de Buenos Aires:

Las reclamaciones de Buenos Aires, como siempre apoyadas en la fuerza, no se hicieron esperar. Los portugueses, a quienes naturalmente la distancia que los separaba de los recursos los perjudicaba, procuraron convencer al gobernador de Buenos Aires de que la ocupación de aquel punto era necesaria para evitar que otros pobladores europeos se instalasen allí. [...] El recurso dilatorio no produjo ningún efecto, pues el gobernador de Buenos Aires, que antes de esto había recibido un ejército y alistado una escuadra, marchó contra Montevideo. Era, como

\footnotetext{
60 "S. Magestade Christianissima reconhece pelo presente Tratado, que as duas margens do Rio das Amazonas, assim Meridional, como Septentrional, pertenceu em toda a Propriedade, Dominio, \& Soberania a Sua Magestade Portugueza, \& promette, que nem elle, nem seus Descendentes, Successores, \& Herdeiros farão jamais algúa pertencção sobre a Navegação, \& uso do dito Rio, cõ qualquer pretexto que seja". Artículo $10^{\circ}$ del Tratado de Utrecht del 11 de Abril de 1793. Soares, Fronteiras, 122.
} 
se ve, toda la margen septentrional del Plata la que estaba bajo el ojo vigilante de la gente de la margen opuesta ${ }^{61}$.

En el mismo sitio donde los portugueses habían intentado establecerse, los españoles comenzaron la edificación San Felipe de Montevideo, a partir de 1725.

Diez años más tarde Colonia del Sacramento iba a ser, otra vez, motivo de beligerancia en Suramérica. El 22 de enero de 1735 la policía española entró en la residencia del embajador portugués en Madrid, con la intención de arrestar a uno de sus empleados ${ }^{62}$. Cuando la noticia del hecho llegó a Lisboa, un acto semejante fue perpetrado contra la casa del embajador español. Esto fue motivo suficiente para el rompimiento de las relaciones diplomáticas entre los dos países.

El hecho sucedió precisamente cuando la diplomacia portuguesa intentaba, una vez más, adquirir una mayor autonomía y subir escalones de prestigio y reconocimiento entre las otras cortes europeas. Ejemplo de esto fue la creación de la Secretaria de Estado dos Negócios Estrangeiros e da Guerra el 28 de julio de $1736^{63}$. El soporte económico que pareció respaldar este nuevo cambio de posición durante el reinado de don Joao $\mathrm{V}$, fue el descubrimiento de oro en Brasil, confirmado a partir de los primeros años del siglo XVIII: "Ya bien establecida la dinastía de Braganza y enriquecido el país por los recursos mineros del Brasil, la corte de Lisboa le quiso hacer sentir muy bien a todos los Estados la independencia portuguesa" ${ }^{\$ 64}$.

La ruptura de 1736 tuvo como consecuencia inmediata un nuevo cerco a Colonia impuesto por los españoles de Buenos Aires, que duró desde noviembre de 1735 hasta octubre de 1736 y que fue rechazado, con mucho costo, por los defensores de Colonia: "Los defensores comieron caballos, perros, gatos y todo tipo de animales domésticos" ${ }^{\$ 5}$. En seguida se firmó el armisticio, patrocinado por la intervención franco-británica ${ }^{66}$.

La cuestión central que debe ser tratada a propósito de la instalación e insistente defensa y mantenimiento de Colonia del Sacramento, sin embargo, consiste en las motivaciones políticas y/o económicas básicas que llevaron a esto. La mejor comprensión de este fenómeno permite indirectamente, por extensión, verificar el proyecto más elemental de Portugal con relación a la

\footnotetext{
61 “As reclamações de Buenos Aires, como sempre apoiadas na fôrça, não se fizeram esperar. Os portuguêses, a que naturalmente a distância que os separava de recursos embaraçava, procuraram convencer o governador de Buenos Aires de que a ocupação daquele ponto era necessária, para evitar que outros povos europeus se instalassem ali. [...] O recurso aleatório nenhum efeito produziu, pois o governador de Buenos Aires, que antes de mais nada havia reunido um exército e aprestado uma esquadra, marchou contra Montevidéu. Era, como se vê, tôda a margem setentrional do Prata sob o olhar vigilante da gente da margem oposta". Cidade, Lutas, 30.

${ }^{62}$ Ibídem, 34

${ }^{63}$ Martínez, História, 184.

64 "Já bem enraizada a dinastia de Bragança e enriquecido o País pelas receitas mineiras do Brasil, a corte de Lisboa quis fazer sentir bem a todos os Estados a independência portugueza”. Ibídem, História, 183.

65 "Os defensores comeram cavalos, cães, gatos e tudo quanto foi animal doméstico". Cidade, Lutas, 35.

${ }^{66}$ Martínez, História, 184.
} 
región platina como un todo, con especial atención al actual territorio del Estado de Rio Grande do Sul.

El periodo posterior a la fundación de Colonia del Sacramento hasta la firma del Tratado de San Ildefonso ${ }^{67}$ en la región platina, tuvo como característica principal un gran esfuerzo hacia la ocupación del inmenso territorio de la orilla izquierda del río Uruguay. Obviamente, este esfuerzo se concentró en áreas consideradas estratégicas en los litorales fluviales y marítimos de la región, con pocas excepciones. En el caso portugués, la región de Laguna, las barras de los ríos principales como el Mampituba, el Tramandai y el Rio Grande de São Pedro (canal de São Gonçalo). En el caso español, los litorales internos de los campos orientales, en los ríos Uruguay y de la Plata y en el litoral Atlántico, hasta Maldonado.

En este contexto se realizaron las fundaciones de Rio Grande, Viamão, Porto Alegre, Río Pardo, Montevideo, Santo Domingo Soriano y Maldonado, entre otras. Estos primeros establecimientos urbanos son una novedad y, en este primer momento de su existencia, representaban marcos todavía sin vigor, diferenciándose del casi desierto demográfico de su alrededor ${ }^{68}$.

Contingentes humanos de carácter mas fijo se vieron posteriormente en la zona rural, atraídos por la abundancia de tierras y por el ciclo del cuero, que se iniciaba. Se puede suponer, haciendo una antropologización muy empírica y superficial, que fueron individuos con tendencia al riesgo, a la aventura y al enriquecimiento fácil; y que aunque no se encontraban emocionalmente endurecidos cuando llegaron en estas tierras, pasaron necesariamente por este proceso, debido a la necesidad de subsistencia en un mundo que se presentaba duro y hostil.

La fundación del presidio Jesús María José (1737) permitió el florecimiento en su cercanía de la villa de Rio Grande de São Pedro que fue, a su vez, el primer núcleo urbano del actual Estado del Rio Grande do Sul. El establecimiento del fuerte fue decisión del brigadier José da Silva Paes, el 1 de noviembre de aquel año, al regresar de campaña durante la guerra de 1735-1737, en el río de la Plata ${ }^{69}$.

\footnotetext{
${ }^{67}$ De hecho fueron dos tratados: uno preliminar en 1777 y el definitivo de 1778 (que en realidad se firmó en El Pardo).

68 "Desde a fundação de Sacramento e durante a primeira metade do século XVIII, as disputas entre espanhóis e portugueses não haviam se restringido à posse desta cidadela. Elas tiveram dois outros objetivos: o controle integral da margem setentrional do Río da Prata e o domínio sobre as terras das campanhas da Banda Oriental e das que, futuramente, comporiam o Rio Grandedo Sul. Como resposta a tais propósitos, os portugueses haviam fundado os fortes de Santa Tereza e de São Miguel e, mais tarde, o de Jesus Maria José que deu origem à cidade de Río Grande. Tentaram, também, a criação de outro núcleo de povoamento junto ao Río da Prata, em área que corresponde atualmente a Montevidéu. Os espanhóis, apreensivos com a descida dos portugueses em direção ao sul, haviam tentado bloquear-lhes o acesso a Sacramento, tanto por terra quanto por mar". Reichel y Gutfreidn, As raizes, 65.

${ }^{69}$ Décio Vignoli das Neves, Vultos do Rio Grande-da Cidade e do Municipio (Santa Maria: Pallotti, 1981), 1: 17-36.
} 
La localidad de Rio Grande tiene la característica de ser el puerto marítimo de mejor calidad entre Laguna, en el Brasil y la Laguna de Rocha (las Palomas) ${ }^{70}$, en el Uruguay. Asimismo, aunque no es un puerto de bahía, el ideal para el tipo de transporte marítimo de la época, sí es un puerto de barra fluvial -en este caso, la laguna de los Patos-, móvil e inestable. Su singularidad, en medio del más grande litoral sin bahías del mundo, lo hizo un punto vital y estratégico para los intereses de los portugueses ${ }^{71}$.

El puerto de Rio Grande pasó a ejercer una función vital para la ocupación del dicho Continente de São Pedro. De hecho, ninguna ocupación europea efectuada más al interior tenía grandes posibilidades de subsistencia sin la existencia de aquel puerto. No resulta exagerado decir, por lo tanto, que el Rio Grande do Sul portugués debió su nacimiento y su posterior existencia a aquella fundación efectuada en 1737.

La explicación para una afirmación de esta importancia se origina de la naturaleza misma de la circulación de productos y personas, en un contexto occidental y noindígena, por lo menos hasta la llegada de los ferrocarriles. El transporte de mayor envergadura y de más rapidez fue hecho, esencial y básicamente, a través de la navegación. El éxito o fracaso de proyectos geopolíticos se fundamentaba, a largo plazo, en la posibilidad de promover el trasbordo de mercancías y bienes de cualquier naturaleza (no sólo económica), utilizando como base un puerto o una red de puertos ${ }^{72}$.

A pesar de las profundas diferencias interpretativas, se acepta entre los historiadores que uno de los más grandes conflictos suramericanos, la Guerra del Paraguay, fue motivada, antes que cualquier otra cosa, por la necesidad paraguaya de encontrar una salida al mar. En este tópico reside la importancia fundamental del Rio Grande de São Pedro para todo el desarrollo posterior de la historia geopolítica platina. Aunque no siempre haya sido mencionada de manera directa en los principales eventos políticos posteriores, su presencia geográfica siempre determinó su significación simbólica y su papel socioeconómico para todo su hinterland.

\footnotetext{
${ }^{70}$ Igualmente la Laguna de Rocha no es la más adecuada para el recibimiento de navíos, y fue preterida por el puerto de Maldonado. Sobre la fundación de Río Grande: "por se tratar da única abertura marítima entre Santa Catarina e a bôca do Río da Prata" ver Cidade, Lutas, 36.

71 “A Povoação principal deste Continente, q' se denomina Villa de São Pedro está situada na latitude de $31^{\circ}$, e 58', e na longitude de $334^{\circ}$, e $25^{\prime}$. A sua barra hê perigoza, pelos $\mathrm{m}^{\text {tos }}$ bancos mudaveis q' tem de arêa, segundo as enchentes, e correntezas d'agoas. Passando este obstaculo, achão as Embarcaçoens hum optimo laga mar, para se abrigarem, e ancorarem" (Arquivos Nacionais - Torre do Tombo, Lisboa. Manuscritos do Brasil - no. 47, todo el documento). Nótese que la expresión "laga mar" que aparece en este texto, se refiere a la laguna de los Patos.

${ }^{72}$ Fernando Camargo, Britânicos no Prata: caminhos da hegemonia (Passo Fundo: Ediupf, 1996), 27. Algunos proyectos parece que fracasaron tempranamente por este motivo, confirmando este punto de vista. El Protectorado de Artigas, ambicioso proyecto político, falló, sobre todo, en encontrar una salida portuaria, en la medida en que no pudo mantener Montevideo y nunca consiguió controlar Buenos Aires. Sin éstos, los puertos del litoral de los ríos Paraná y Uruguay quedaban relegados a la subutilización. Los revoltosos Farrapos del Rio Grande do Sul no lograron someter el puerto de Rio Grande. Tampoco pudieron mantener y, después de perdida, reconquistar, Porto Alegre; hecho que los llevó, en una tentativa desesperada, a ocupar el puerto de Laguna, transformándolo en la efímera y quijotesca Republica Juliana (una extensión de la República Piratini, de los farrapos).
} 
En el lado español, en esta época, las misiones jesuíticas del Paraguay y del Uruguay alcanzaron el punto culminante de su desarrollo socioeconómico ${ }^{73}$. Este fenómeno histórico, como ya se ha dicho antes, seguía su ritmo evolutivo como un reducto diferenciado pero integrado, en el universo colonial platino.

Los conflictos entre las dos fuerzas opuestas en expansión en Suramérica, el bandeirantismo paulista y el misionerismo jesuítico, provocaron el traslado de las poblaciones reducidas a la orilla derecha del río Uruguay (actual Provincia de Misiones, Argentina), donde quedarían más protegidas frente a las agresivas expediciones de caza de esclavos indígenas luso-brasileñas. Pero los ataques bandeirantes sufrieron un freno más efectivo en la derrota sufrida frente a los indios guaraníes, que fueron autorizados a formar milicias ${ }^{74}$, en la batalla de Mbororé en el año de $1641^{75}$.

Desde la segunda mitad del siglo XVII los guaraníes y los jesuitas se venían consolidando, una vez más, en la región ubicada en la orilla izquierda del río Uruguay, dando origen al fenómeno que ha sido consagrado en la historiografía como los Siete Pueblos de las Misiones. Las reducciones o misiones de San Luis, San Borja, San Miguel, San Ángel, San Juan, San Lorenzo y San Nicolás, se venían desarrollando con gran vitalidad y se transformaron en las "perlas" de la experiencia misionera jesuítica.

La base territorial que ocupaban fue delimitada por los ríos Uruguay, Ibucuy y Jacuy, pero sus influencias se extendían a través de las llamadas "estancias" de los pueblos, hasta los campos orientales, en las cercanías del río Negro. Las estancias se configuraban como un lugar de reserva de caza, en las cuales el ganado bovino, principalmente, y el equino y el ovino, secundariamente, se desarrollaban libremente, con una mínima intervención humana en el sentido de implementar mejoras y sin la utilización de prácticas pecuarias más avanzadas, como las conocidas en Europa en aquellos tiempos ${ }^{76}$.

La presión de la población blanca en la campiña creció a partir del llamado de atención hacia las inmensas riquezas en cueros, disponibles en los campos platinos, al norte del río de la Plata, con la fundación y las disputas relativas a Colonia del Sacramento ${ }^{77}$. Esta presión tenía, ahora, establecimientos urbanos o casi urbanos, que custodiaban mejor el avance. Este hecho puso en la mira de los intereses coloniales de ambas nacionalidades la alardeada prosperidad de los

\footnotetext{
${ }^{73}$ Aurélio Porto, História das Missões Orientais do Uruguai, 2a. ed. revisada y mejorada por P. Luís Gonzaga Jaeger, S. J. 2 partes (Porto Alegre: Livraria Selbach, 1954), parte 2, 162-197.

${ }^{74}$ Arno Alvarez Kern, Missões: uma utopia politica, Série Documenta 14 (Porto Alegre: Mercado Aberto, 1982), 262 y 263. Ver también Porto, donde se lee: "O Decreto real de 21 de Maio de 1640, concedia-lhes o uso de armas de fogo". Porto, História, parte 2, 14.

${ }^{75}$ Porto, História, parte 1, 181-196.

${ }^{76}$ También hubo criaderos de mulas, aunque marginalmente, ya que no puede hacerse sin control como para los otros tipos de ganado. Un ejemplo conocido de este tipo de criaderos fue la estancia llamada Calera de las Huérfanas (Uruguay).

${ }^{77}$ Sobre este tema, véase Assunção, El gaucho, 1: 217-220.
} 
pueblos misioneros. Hay que agregar en este tema la probable indignación velada que se sentía con respecto a los privilegios reales concedidos a los jesuitas y sus misiones religiosas.

Es posible comparar ese cuadro con una gran tenaza luso-hispánica cerrándose sobre aquel enclave; aquel cuerpo diferente y poco identificado con el resto de las colonias ibéricas circundantes. La situación de la Compañía de Jesús en Europa y en el resto del mundo tampoco inspiraba confianza, ya que los años de preeminencia junto a las naciones católicas europeas y junto al papado mismo, parecían haber creado un profundo sentimiento de malestar y ya comenzaban a escasear los que podían prestar un franco apoyo político a los ignacianos.

La Compañía de Jesús se involucró en un interesante proceso de desafío al poder central de los reinos en los cuales estuvo establecida. Aparentemente, tal hecho no se debió a una oposición directa a las autoridades temporales, pero el desafío ocurría espontáneamente, al tiempo que la Compañía de Jesús ocupaba espacios que los Estados, cada vez más, reclamaban como suyos ${ }^{78}$.

La cuestión adquiría más fuerza en la medida en que crecía la postura política que se conoce como despotismo ilustrado, ya que ésta entendía como prerrogativa estatal el control del timón de la cultura, de la educación y del desarrollo científico y tecnológico. De cualquier manera, el jesuitismo llegó a identificarse con formaciones políticas indeseables, en contextos en los cuales las monarquías absolutas de los últimos momentos del Ancién Régime veían la sumisión de la nobleza y del clero como una tarea necesaria para el desarrollo nacional, como ya había ocurrido en otros tiempos.

Los jesuitas enfrentaban serios problemas junto a los gobiernos de Portugal y de Austria. La España borbónica también fue influenciada por esta misma preocupación frente a los ignacianos ${ }^{79}$. En Portugal esto quedó claro más tarde con la política pombalina, que dio como resultado la completa erradicación de la orden jesuita en aquel país y en sus colonias.

\footnotetext{
78 "Mesmo antes de deflagrar a insubordinação dos índios missioneiros contra a injusta aplicação do Tratado de 1750, uma trama insidiosa se tecia na Europa para envolver em suas malhas o que a política reacionária da época chamava de "poderio jesuítico". Porto, História, parte 2, 242. Véase una interesante discusión sobre el tema en Hemeterio J. Velloso da Silveira, As Missões Orientais e seus antigos domínios (Porto Alegre: Typographia da Livraria Universal de Carlos Echenique, 1909), 51-82.

79 "Envy and fear fueled this monarchical enmity, fed by rumors spread by enemies of the Jesuits, not a few of them within competing religious orders. The Jesuits, it was said, had secret silver mines on the mission lands; they were stealing the king's treasure; they planned to declare their 'state' independent of the Spanish crown. None of this was true: there were neither mines, nor treasure, nor a hint of a serious sentiment for rebellion. When King Charles' troops arrived at the missions to arrest the Jesuits, they went quietly. They didn't have to, for they controlled a military force greater than that at the disposal of the governor of Buenos Aires, Francisco Bucareli, the man charged with carrying out the expulsion. These were the Indian militias, fanatically loyal to the 'padres'. They had been formed, with royal sanction, to defend the missions from Brazilian slavers. They became a bulwark against incursions into Spanish territory and were frequently deployed to defend Buenos Aires against the French, Dutch, and English". Richard O’Mara, "The Jesuit Republic of South America", The Virginia Quarterly Review 75, no. 2 (1999), 525.
} 
En este contexto se celebró el 8 de febrero de 1750 el Tratado de Madrid ${ }^{80}$, entre las dos naciones ibéricas. Los términos del tratado, entre otras innumerables consideraciones anunciaban la entrega a España de Colonia del Sacramento, así como la entrega a Portugal de los Siete Pueblos de las Misiones Orientales del Uruguay.

El tratado de 1750 no fue una pieza más en este proceso de presión sobre los jesuitas. Por más tentador que parezca, es difícil establecer un nexo documentalmente sustentado que vincule aquel tratado y la consecuente entrega de los Siete Pueblos a Portugal, como si esto fuera parte de una estrategia premeditada de ataque a las posiciones de los jesuitas. Esto, sin embargo, tampoco significa que los términos del acuerdo, en lo que toca a aquellas reducciones, no hayan venido al encuentro de fuertes intereses políticos y económicos, especialmente coloniales.

Por otro lado, fue con el Tratado de Madrid que comenzó la decadencia, jamás recuperada, de la simbiosis entre los guaraníes reducidos y los padres de la Compañía de Jesús e, incluso, con religiosos católicos de diferentes orígenes y las autoridades laicas coloniales. Inclusive en el corto periodo de tiempo en que los jesuitas retornaron a la orilla izquierda del río Uruguay hasta la expulsión de la orden de España (1761-1767), no hubo manera de recuperar las condiciones anteriores, no sólo por las destrucciones materiales ocurridas, sino también por el trauma que el conflicto originado del tratado -la Guerra Guaraní- provocó en aquella población ${ }^{81}$.

En este mismo enfoque, bajo el ángulo interno del universo "guaraní-misionero", el conflicto dejó profundas secuelas, que no tienen origen en la expulsión de los padres jesuitas, sino por el hecho de haber permitido que afloraran sus propias tensiones y contradicciones ${ }^{82}$.

El Tratado de Madrid, a su vez, se transformó en un marco de transición en las relaciones diplomáticas entre las dos Coronas ibéricas en Suramérica, porque preveía, más allá de una solución de gabinete, siguiendo el ejemplo de la larga secuencia de acuerdos anteriores, la averiguación, in loco de las condiciones del tratado, de los límites que iban a implementarse y de la fijación de marcos delimitantes.

\footnotetext{
${ }^{80} \mathrm{La}$ ratificación portuguesa ocurrió antes, el 26 de enero del mismo año, pero la última ratificación, la española, se hizo en esta fecha, conforme consta en el exordio del tratado.

81 "The Jesuits' departure in 1767 was a catastrophe for the Indians under their care. They felt betrayed. Hadn't they been loyal subjects? Paid their yearly tithes to the crown? Hadn't they even fought the king's enemies?'. O'Mara, "The Jesuit", 526. Obsérvese que el autor se está refiriendo aquí a todo el universo de las misiones jesuitas en América del Sur y no solamente a los Siete Pueblos del río Uruguay.

82 “A Guerra Guaranítica é o tema recorrente na história das Missões jesuítico-guaranis. Historicamente, significou a maior crise da Província do Paraguai e, em especial, dos Sete Povos localizados no atual território Río-grandense. Ela desencadeou o processo de desestabilização do espaço social missioneiro. De certa forma, tensionou suas esferas internas, singularmente entre 1752 e 1757, periodo dos conflitos com os exércitos coligados de Espanha/Portugal e, também, de divergências internas entre os Sete Povos, cabildos e caciques. Essa 'cizânia' interguarani, conforme expressão do padre Henis, ficou demonstrada nas notas. Desde 1754, revelaram-se 'discórdias no exército dos índios, de sorte que, algumas vezes, [quase tiveram] guerra civil, ou intestina". Tau Golin, A Guerra Guaranítica: como os exércitos de Portugal e Espanha destruíram os Sete Povos dos jesuitas e índios guaranis no Rio Grandedo Sul (1750-1761) (Passo Fundo y Porto Alegre: EDIUPF; Editora da Universidade-UFRGS, 1998), 559.
} 
Además de esto, el Tratado de Madrid marcó el fin de las desavenencias mantenidas a partir de la lógica del meridiano de Tordesillas. Aquella línea meridiana quedaba finalmente sepultada con el nuevo trazado divisorio entre Portugal y España en el mundo. También, en este tratado, quedó consagrado el principio del Uti Possidetis, como principio básico para administrar las diferentes pretensiones de los litigantes ${ }^{83}$.

Intentar reconstituir los hechos relativos a la Guerra Guaraní, bajo la óptica de un enfrentamiento de nacionalidades distintas es, en verdad, incurrir en un error de origen, pues lo que ocurrió fue una rebelión de un grupo de súbditos españoles contra las disposiciones de un acuerdo de límites entre su Corona y la nación vecina. En otras palabras, no se puede reforzar la idea, muy difundida en la historiografía tradicional, de un Estado dentro del Estado, teniendo en cuenta que, aun en circunstancias muy penosas para las comunidades guaraní-misioneras como los reclutamientos militares constantes, nunca se observó un desafío directo a la autoridad central del mundo colonial español. Los guaraníes reducidos fueron tanto o más fieles súbditos de Su Majestad Católica como cualquier criollo o peninsular en Suramérica ${ }^{84}$.

Esto puede parecer una paradoja, pues se viene diciendo, a lo largo del texto, que las misiones guaraníes tenían una formación distinta de las otras instituciones coloniales hispánicas. Poseían un tipo de autonomía que fácilmente se confundiría con un privilegio, bajo la óptica de los otros agentes sociales y políticos de la época y opuesta a los fuertes intereses económicos de grupos coloniales de las nacionalidades europeas presentes en el Cono Sur.

La Compañía de Jesús enfrentaba problemas de naturaleza semejante en Europa, como ya se advirtió. La trágica solución que se le dio a la oposición guaraní al Tratado de Madrid no se explica solamente con argumentos economicistas, politicistas o culturalistas frente al fenómeno, sino a partir de una observación más global de los eventos. Con el paso del tiempo y, principalmente, con la expansión de las fronteras colonialistas (no las político-diplomáticas, sino las socioeconómicas) la presencia de la estructura representada por el trípode guaraníesmisiones-jesuitas se volvió insostenible.

Para la evolución histórica de lo que hoy llamamos Rio Grande do Sul y República Oriental del Uruguay, este efecto del Tratado de Madrid, sumado a la posterior expulsión de los jesuitas de España y la extinción de la orden por el Papa, significó el final de un modo de vida muy especifico, existente apenas en el interior de Suramérica y con una duración efímera. Los

\footnotetext{
83 “Alexandre de Gusmão, diplomata português nascido no Brasil, levantou então o princípio do Uti possidetis, argumentando que o direito ao território devia caber ao povo que o povoara, que o conquistara aos primitivos habitantes. A consagração deste princípio beneficiava os lusitanos na América do Sul, onde os paulistas haviam provocado o 'recuo do meridiano', mas beneficiava os espanhóis na Ásia, onde eles haviam ocupado as Filipinas". Manuel Correia de Andrade, Geopolítica do Brasil, Série Princípios 165 (São Paulo: Editora Ática, 1989), 16.

84 "Ao contrário, a situação de dependência à sociedade global espanhola fica evidente quando se analisam variáveis tais como o pagamento de tributos, a prestação de serviços militares, as visitas de inspeção de governadores e bispos, a delegação de autoridades aos missionários e indígenas pelos detentores do poder ou seus representantes. A área ocupada pelos Trinta Povos estava inserida no interior dos territórios do império espanhol e nas proximidades de duas capitais provinciais". Kern, Missões, 264.
} 
guaraníes cristianizados, mientras tanto, intentaron desesperadamente mantener intactas sus instituciones, transformando en los mitos e iconos de su decadencia, lo que fue hecho y presencia histórica en los tiempos de su apogeo.

En el teatro de la esgrima diplomática entre las naciones ibéricas, el Tratado de Madrid no fue el idealizado fin de las cuestiones de fronteras y límites. La desconfianza mutua, enraizada por casi cinco siglos de enfrentamientos ${ }^{85}$, impidió que los términos del acuerdo fueran llevados a cabo integralmente ${ }^{86}$.

\section{Bibliografía}

Andrade, Manuel Correia de. Geopolítica do Brasil. Série Princípios 165. São Paulo: Editora Ática, 1989.

Anónimo. Noticias sobre el Río de la Plata: Montevideo en el siglo XVIII. Nelson Martínez Díaz, ed. Colección "Crónicas de América". Historia 16. Madrid: Información y Revistas, S.A., 1988.

Assunção, Fernando O. El gaucho - Estudio socio-cultural. 2 tomos. Montevideo: Dirección General de Extensión Universitaria - División Publicaciones y Ediciones, 1978.

Bandeira, Moniz. O expansionismo brasileiro: o papel do Brasil na Bacia do Prata-Da colonização ao império. Rio de Janeiro: Philobiblion, 1985.

Bethell, Leslie, org. História da América Latina: América Latina Colonial. 2 vols. São Paulo: Ediusp; Brasília: Fundação Alexandre de Gusmão, 1999.

Camargo, Fernando. Britânicos no Prata: caminhos da hegemonia. Passo Fundo: Ediupf, 1996.

Cervo, Amado L. y Mário Rapoport, org. História do Cone Sul. Rio de Janeiro: Revan; Brasília: Editora Universidade de Brasília, 1998.

Cesar, Guilhermino. O contrabando no sul do Brasil. Caxias do Sul y Porto Alegre: Universidade de Caxias do Sul; Escola Superior de Teologia São Lourenço de Brindes, 1978.

Cidade, Francisco de Paula. Lutas, ao Sul do Brasil, com os espanhóis e seus descendentes (1680-1828). Biblioteca Militar, vols. CXXVII y CXXVIII. Rio de Janeiro: Ministério da Guerra, 1948.

Defarges, Philippe Moreau. Introdução à geopolítica. Lisboa: Gradiva, 2003.

Early, Edwin et al. History Atlas of South America. Nueva York: MacMillan, 1998.

Espírito Santo, Miguel Frederico do. O Rio Grande de São Pedro entre a fé e a razão: introdução à história do Rio Grande do Sul. Porto Alegre: Martins Livreiro, 1999.

\footnotetext{
${ }^{85} \mathrm{Si}$ se cuenta el periodo anterior a la conquista de América.

86 "A Colônia de Sacramento, contrariando o previsto no Tratado de Permuta, não foi devolvida mas, pelo contrário, foi retida mediante recursos dilatórios e fortificada pelos portugueses". Cervo y Ropoport, História, 44. También: "exige a imparcial verdade que se confesse que já então se negociava esta demarcação sem desejar concluí-la, esquadrinhando-se de parte a parte pretextos especiosos para paralisá-la, quiçá por insinuações privadas como pelo menos pareceram confirmar os fatos posteriores". Pinheiro, Anais, 87.
} 
Ferro, Marc. História das Colonizações: das conquistas às independências, séculos XIII a XX. São Paulo: Companhia das Letras, 1996.

Flores, Moacyr. História do Rio Grande do Sul. Porto Alegre: Nova Dimensão, 1997.

García, Emanuel Soares da Veiga. As duas Argentinas. Série Princípios 194. São Paulo: Ática, 1990.

O comércio ultramarino espanhol no Prata. Coleção Khronos 13. São Paulo: Editora Perspectiva, 1982.

Golin, Tau. A Guerra Guaranítica: como os exércitos de Portugal e Espanha destruíram os Sete Povos dos jesuitas e indios guaranis no Rio Grande do Sul (1750-1761). Passo Fundo y Porto Alegre: EDIUPF; Editora da Universidade-UFRGS, 1998.

Kern, Arno Alvarez. Missões: uma utopia política. Série Documenta 14. Porto Alegre: Mercado Aberto, 1982.

Laviana Cuetos, María Luisa. La América española, 1492-1898: de las Indias a nuestra América. Colección Historia de España 14. Madrid: Ediciones Temas de Hoy, 1996.

Magnoli, Demétrio. O corpo da pátria: imaginação geográfica e política externa no Brasil. São Paulo: Editora da Universidade Estadual Paulista-Moderna, 1997.

Martínez, Pedro Soares. História diplomática de Portugal. 2a. ed. Lisboa: Verbo, 1992.

Neves, Décio Vignoli das. Vultos do Rio Grande -da cidade e do município. Tomo Primero. Santa Maria: Pallotti, 1981.

O’Mara, Richard. "The Jesuit Republic of South America". The Virginia Quarterly Review 75, no. 2 (1999).

Olaizola, José Luis. Bartolomé de Las Casas, crónica de un sueño. Colección Memoria de la Historia 57. 3a. ed. Barcelona: Editorial Planeta, 1992.

Pinheiro, José Feliciano Fernandes (Visconde de São Leopoldo). Anais da Província de São Pedro. Série Documenta 11. Porto Alegre: Mercado Aberto, 1982.

Porto, Aurélio. História das Missões Orientais do Uruguai. Segunda edición revisada y mejorada por P. Luís Gonzaga Jaeger, S. J. 2 partes. Porto Alegre: Livraria Selbach, 1954.

Reckziegel, Ana Luiza Setti. A diplomacia marginal: vinculação entre o Rio Grande do Sul e o Uruguai, 1893-1904. Porto Alegre. Tesis. Porto Alegre: PUCRS, 1997.

Reichel, Heloísa J. e Ieda Guttfreind. As raizes históricas do Mercosul: a Região Platina colonial. São Leopoldo: Unisinos, 1996.

Silveira, Hemeterio José Velloso da. As Missões Orientais e seus antigos domínios. Porto Alegre: Typographia da Livraria Universal de Carlos Echenique, 1909.

Slatta, Richard W. Gauchos and the Vanishing Frontier. Lincoln: University of Nebraska Press, 1992.

Soares, José Carlos de Macedo. Fronteiras do Brasil no Regime Colonial. Coleção Documentos Brasileiros 19. Rio de Janeiro: Livraria José Olympio Editora, 1939.

Souza Docca, Emílio Fernandes de. Limites entre o Brasil e o Uruguai. Rio de Janeiro: Oficina Gráfica do Estabelecimento Central de Intendencia, 1939.

Telo, António José. Do Tratado de Tordesilhas à Guerra Fria: reflexões sobre o sistema mundial. Blumenau: Editora da FURB, 1996. 
Vellinho, Moysés. Capitania d'El Rei: aspectos polêmicos da Formação Rio-Grandense. 2a. ed. Coleção Província. Porto Alegre: Editôra do Globo, 1970.

Fronteira. Coleção Província. Porto Alegre: Editora Globo-URGS, 1975.

Viana, Francisco. Argentina, civilização e barbárie. Série História Viva. São Paulo: Atual, 1990.

Viana, Oliveira. Populações meridionais do Brasil. Vol. 2. "O Campeador Rio-Grandense". Rio de Janeiro: Paz e Terra, 1974.

Fecha de recepción del artículo: 9 de junio de 2003

Fecha de aceptación: 22 de agosto de 2003 